\title{
From semiosis to semioethics: The full vista of the action of signs
}

\author{
John Deely \\ University of St Thomas \\ 3800 Montrose Blvd, Houston, TX 77006, USA \\ e-mail: deelyj@stthom.edu
}

\begin{abstract}
How anything acts depends upon what it is, both as a kind of thing and as a distinct individual of that kind: "agere sequitur esse" - action follows being. This is as true of signs as it is of lions or centipedes: therefore, in order to determine the range or extent of semiosis we need above all to determine the kind of being at stake under the name "sign". Since Poinsot, in a thesis that the work of Peirce centuries later confirmed, the proper being of signs as signs lies in a relation, a relationship irreducibly unifying three distinct terms: a foreground term representing another than itself — the representamen or sign vehicle; the other represented - the significate or object signified; and the third term to or for whom the other-representation is made - the interpretant, which need not be a person and, indeed, need not even be mental. The action of signs then is the way signs influence the world, including the world of experience and knowledge, but extending even to the physical world of nature beyond the living. It is a question of what is the causality proper to signs in consequence of the being proper to them as signs, an indirect causality, just as relations are indirectly dependent upon the interactions of individuals making up the plurality of the universe; and a causality that models what could or might be in contrast to what is here and now. To associate this causality with final causality is correct insofar as signs are employed in shaping the interactions of individual things; but to equate this causality with "teleology" is a fundamental error into which the contemporary development of semiotics has been inclined to fall, largely through some published passages of Peirce from an essay within which he corrects this error but in passages so far left unpublished. By bringing these passages to light, in which Peirce points exactly in the direction earlier indicated by Poinsot, this essay attempts a kind of survey of the contemporary semiotic development in which the full vista of semiosis is laid out, and shown to be co-extensive with the boundaries of the universe itself, wherever they might fall. Precisely the indirect extrinsically specificative formal causality that signs exercise is what enables the "influence of the future" according to which semiosis changes the
\end{abstract}


relevance of past to present in the interactions of Secondness. Understanding of this point (the causality proper to signs) also manifests the error of reducing the universe to signs, the error sometimes called "pansemiosis".

\section{Contents}

1. Why so late?

2. The difficulty of realizing the ubiquity of signs in human awareness and in nature

2.1. Seeing the whole of being: subjectivity, suprasubjectivity, intersubjectivity, objectivity

2.1.1. Subjectivity, at the base of intersubjectivity

2.1.2. The being of relations: suprasubjectivity and intersubjectivity. 444

2.1.3. How objects differ from things even when they are one and the same existent

2.1.4. Suprasubjectivity and objectivity in contrast to physical environment

2.2. The singularity of relation as enabling thirdness

2.2.1. Objective world in contast to physical environment: the Umwelt .....

2.2.2. The place and role of the Innenwelt

2.2.3. Whence semiotics takes its "point of departure", finds its "proper stand

3. The necessity of linguistic communication for developing any science, including the doctrine of signs

3.1. Why did semiology precede semiotics when the need to study signs first became generally accepted?

3.2. The linguistic approach, necessity and limitations 456

3.2.1. What language as semiosis consists in 458

3.2.2. Demonstrating the inadequacy of linguistic analysis as an autonomous approach to philosophical questions

4. In search of the broadest sense of sign

4.1. Why Sebeok's final view of semiosis as co-extensive with life is not broad enough

4.2. Semiosis as cause no less than condition of life

4.3. The crucial point over which Peirce and much semiotic development after him stumbled: the causality proper to signs as signs

1 This essay was developed out of exchanges with Susan Petrilli in connection with her preparation of the Thomas A. Sebeok Fellow Plenary Lecture for presentation at the 33rd Annual Meeting of the Semiotic Society of America, 17 October 2008, now published in the first "Sebeok Fellow Special Issue" of The American Journal of Semiotics 24(4): 1-48 (2008), which is why the two texts cross on various theoretical points. 
4.3.1. The action of signs vis-à-vis finality 470

4.3.2. The crucial gap in Peirce's Collected Papers 471

4.3.3. Signs as vehicles versus signs as signs

4.3.4. Recognizing the "ideal limit" in vehicles of communication ... 474

4.3.5. Tracing the error to its "common sense" source ...................... 477

4.3.6. Modeling "maybe"

5. "Rendering inefficient relations efficient" 478

5.1. Semiosis as an influence of the future 479

5.2. The transition within semiosis to semioethics

In my book, Basics of Semiotics (1990; 2005), I examined the many parts and aspects of semiotics in its development as the "doctrine of signs", in order to sort out the basic notions. There are subdivisions of semiotics, to be sure; but there is no "higher order" of knowledge that is independent of the action of signs, not in the sphere of finite beings. $^{2}$ Having seen the parts in relation to the whole, here I would

2 In an interesting terminological development, Susan Petrilli has spoken of semiotics as a "metasemiosis", not in the sense of going "beyond semiosis", but in the sense of establishing the sphere wherein semiosis becomes an explicit element within, a part of, conscious awareness - a term to mark that boundary between animals which use signs but do not know that there are signs, and semiotic animals: animals which, besides making use of signs, are able to come to know that there are signs and to study the implications of sign activity. There is some merit to this way of speaking, and I have used it myself in the Appendix to Ch. 6 in Deely 2005; but it is a usage that carries some rather serious dangers of creating misunderstanding. The mischievousness of this prefix "meta-" has a long history indeed.

On the positive side, inasmuch as semiotics is the name for knowledge acquired thematically by study of the action of signs, we may legitimately speak of "metasemiosis" as a singular process of semiosis itself wherein human animals go beyond the use of signs generically common to all animals (and to nature itself in its process of development toward a future with possibilities imprevisible within any synchronic horizon of the past as a network of dynamically interacting individuals or "substances") to recognize the existence of signs as a distinct form or mode of being, and to study the action of signs precisely as consequent upon that mode (for "as a thing exercises existence, so does it act upon and is acted upon by its surroundings" - agere et pati sequitur esse).

On the negative side, the use of "metasemiosis" creates a temptation to speak also of "metasemiotics", as if there were or could be for human animals a realm of knowledge independent of the use or action of signs, whereas in fact not even angels are capable of such a knowledge (Deely 2004b). The chief characteristic of such a usage (as I have actually explored at some length: see Deely 2008a: 
like to present an attempt to see the whole of semiotics in relation to its parts, in three senses: first, in the sense of how we got to where we are today as students of the action of signs, the 20th century transition from semiology to semiotics proper; second, in the sense of considering the reach of the action of signs quite independently of human study or awareness of it, but perforce doing so from within anthroposemiosis and with the help of linguistic communication in particular; and third, in the sense of the ethical implications for human conduct that grow out of the awareness of sign-action, what Petrilli and Ponzio (2003; Petrilli 2003) have termed so felicitously "semioethics".

Semiotics is itself a manifestation or result of the action of signs but then so is the whole of human knowledge. So one of the first questions I want to face in this essay is: why did it take human inquiry so long to find a focus in the action of signs, and even then, why did it take so much longer to get beyond that anthropocentric study of signs originally known as "semiology"?

\section{Why so late?}

To say that all knowledge is by way of semiosis is not the same as to say that there are nothing but signs in the universe. ${ }^{3}$ Even though

Section 14-14.5) is oxymoronicity. For just as all knowledge is by way of signs, so all knowledge of signs thematically developed — whether the signs studied be external human artifacts or events of nature, or the internal signs of cognition and cathexis - is "semiotics".

Of course, given the famous "arbitrariness" of linguistic signs, prodded by stipulation, conventionality can always step in. "Metasemiotics", one might say, is not the oxymoronic usage that Todorov suggested, nor the Humpty-Dumpty usage occasionally indulged by Ponzio, but simply that branch of semiotics restricted to the study of "metasemiosis" as the unique feature of anthroposemiosis which distinguishes the human use of signs. Yet "metasemiotics" thus narrowly specified would in effect be a throw-back to the Cartesian notion of res cogitans, prescissively separating human being from the larger world of animals and nature within which the action of signs determinately situates us. In the terms of Aquinas (e.g., see his Summa, Part I, Question 90, "Concerning the knowledge of the separated soul"), we would be inquiring into the semiosis possible for the individual human who has survived bodily death, in effect reducing "metasemiotics" to a version of Husserl's phenomenological "epoché". This is not the most promising side-path along the way of signs, though perhaps it has some theological interest.

3 See the Stjernfelt-Deely exchange: Stjernfelt 2006, Deely 2006 b. 
everything that we can come to know can also, and normally does, come to be a sign in various contexts (by reason of entering into further and various triadic relations), there is more to being than the being of signs.

In fact, the being of signs - constituted, as Peirce and Poinsot unknowingly agreed, ${ }^{4}$ by the triadic relation unifying that relation's foreground support or "vehicle" with what it signifies to or for some third, and grounded in the equiprimordiality of the being of relations with the being of material individuals or substances - cannot exist independently of individuals as interacting, any more than those individuals can exist apart from their interactions or without provenating in and through their interactions intersubjective relations. Being in whatever mode and relation as a mode of being are coextensive

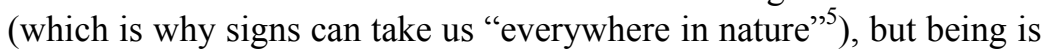
more than the being of relation; and even the being of relation is wider than the being of triadic relation. So all signs in their proper being are triadic relations, and all relations are suprasubjective respecting the being of individuals related, but not all relations are sign relations: whence "the universe is perfused with signs but does not consist exclusively of signs", as I would word a final formula for expressing this matter. ${ }^{6}$

But consider how important semiotics has come to show semiosis to be. Semiosis, the action of signs, is the key to how the future, by an indirect and indeterministic influence on the present, rearranges the relevance of the past; so that not only is semiosis at the heart of human understanding, but even the physical evolution of the early universe in the direction of being able to support life, together with the subsequent evolution of life itself, is no longer a pure question of chance and vis $\grave{a}$ tergo (as such authors as Dawkins ${ }^{7}$ and Dennett ${ }^{8}$ try to argue). All these processes of development as an "upward" movement in nature require to be understood as involving the action of signs in their proper and distinctive relational being as signs.

Yet if this be true, if semiosis is a basic process at work somehow in all of nature, and if indeed all thought, not just human intellectual

Poinsot 1632: Tractatus de Signis Book I, Question 3; Peirce 1904: CP 8.332.

Emmeche 1994: 126.

See Peirce 1906a: CP 5.448; Deely 1994: 160, Gloss 40 on $\uparrow 265$.

Dawkins 1976, 1989.

8 Dennett 1995. 
thought, is in signs, then how is it that semiotics - the awareness of semiosis - is such a late-comer in the theater and repertoire of human knowledge? And why, when the human animal finally did, in the mid20th century, begin to start to commence to thematize the problem of how to understand the workings of signs - why did the majority so engaged see the project initially and almost exclusively in terms of human language and culture?

\section{The difficulty of realizing the ubiquity of signs in human awareness and in nature}

That which is closest to us is the most difficult to perceive. Nothing is closer and more intimate to the experience of all animals than the action of signs. Whence it is that the action of signs is among the things of which it is hardest for us to become thematically aware, and hence will be among the last that we will realize as providing an object of inquiry. Here I am only expressing a summary agreement in this matter with Charles Peirce (1901: CP 1.134):

It is extremely difficult to bring our attention to elements of experience which are continually present. For we have nothing in experience with which to contrast them; and without contrast, they cannot excite our attention. [...] roundabout devices have to be resorted to, in order to enable us to perceive what stares us in the face with a glare that, once noticed, becomes almost oppressive with its insistency. This circumstance alone would be sufficient to render philosophical observation difficult — much more difficult, for example, than the kind of observation which the painter has to exercise. Yet this is the least of the difficulties of philosophy. [...] Quite the worst is, that every man becomes more or less imbued with philosophical opinions, without being clearly aware of it. [...] But even if they are right, or nearly right, they [i.e., the opinions thus arrived at inconsciently or quasi-inconsciently] prevent true observation as much as a pair of blue spectacles will prevent a man from observing the blue of the sky. [...] The more a man is educated in other branches, but not trained in philosophy, the more certain it is that two-thirds of his stock of half-conscious philosophical opinions will be utterly wrong, and will completely blind him to the truth, which he will gradually become unable so much as to conceive. [...] And by a beginner in philosophy I wish to be understood as meaning, in the case of an educated man, one who has not been seriously, earnestly, and single-mindedly devoted to the study of it for more than six or eight years. For there is no other science for which the 
preparatory training requires to be nearly so severe and so long, no matter how great the natural genius of the student may be.

The problem is compounded by the fact that signs in their constitutive being as relations are invisible to sense, for the senses can be directly aware only of material objects that are related (sign-vehicles), not of the signs themselves (the triadic relations that make the material objects of sense-experience come to be called signs in the first place). Thoughts, that is, psychological states as sign-vehicles, are even harder to realize in terms of semiosis; for here even the sign-vehicles and not only the relations they support are not directly accessible to sense. ${ }^{9}$ The semiosis most intimate to us is the most imperceptible element in the whole of our experience.

Aristotle made the point that not everything that appears to us an individual entity really is an individual, but everything that really is a natural unity within a species is a substance. Whence "substance" is a category of being that must be understood, but cannot be directly perceived as such by sense. The same is true of relations as suprasubjective realities, but even more so: for we can at least perceive and form direct images of individuals, even if not of substance as such; but we cannot at all lay before the eyes a visible analogue of what a relation is, only the consequences of changing relations. No wonder that the philosophers in general have had such a difficult time in realizing the singular reality of relations as the only form of mind-independent being which remains exactly what it is essentially even when circumstances render it mind-dependent! Everything that contributes to the difficulty in understanding the singular reality of relation as a mode of being contributes every bit as much to the difficulty in understanding what constitutes signs in their proper and distinctive being. For, since all signs have their proper being in relations, signs cannot be understood apart from relations, even though not all relations are signs: and relations are not the whole of being.

9 “The word 'sign' when applied to the concept", grants Maritain (1959: 389), "does not exactly leap to the tongue", even though it marks a critical step forward in technical exposition. 


\subsection{Seeing the whole of being: subjectivity, suprasubjectivity, intersubjectivity, objectivity}

Recall Aristotle's response to the idea that the whole of reality is simply One and the appearances of Many in this respect are illusory: ${ }^{10}$ "The world is either one or many, but of the many each is one."

\subsubsection{Subjectivity, at the base of intersubjectivity}

It is not an illusion that there are irreducibly many different things in the world and not simply one substance with varying manifestations, he considered. But in order for there to be many there have to be several ones. Diversity, in other words, to be 'real', requires many ones; and these ones thus are subjectivities - things separate from one another, existing in themselves. Distinct natural units, true "individuals", are what Aristotle called substance. A substance is a subject of existence, the prime instance of subjectivity. Yet he also pointed out that subjectivity is only relatively and not absolutely independent, for in addition to substances with their characteristics or individuating accidents there are also relations without certain of which subjects of existence (however else they may vary) could not exist at all. Even substance is relative, not in the sense of being a relation, but in the sense of needing relations in order to be, so that, as Ratzinger has put it, ${ }^{11}$ alongside substance, and interweaving substances into the universe as a whole, "relation is discovered as an equally valid primordial mode of reality". No substance can be without involving itself in relations; no relations can be independently of substances. Individuals are relational beings, but relations are not individuals.

So far so good, but a problem remains: as the 21 st century goes forward, perhaps no word is more used and less thought about than "relation". However, it is crucial to semiotics that this cease to be the case, for a so-called "sign" of the sort one can hear or point to that fails to connect the signified to some third party fails ipso facto

10 Aristotle c.348-347BC, Metaphysics, Book. III, chap. 4, $1001 \mathrm{b6}$.

11 Ratzinger 1970: 132. See also Cobley 2004. And cf. Poinsot 1632: Tractatus de Signis, "Second Preamble", Article 1, esp. 80/1-11, where "distinguitur ab omni entitate absoluta" is understood as "distinguished from every subjective being" or "from the being of every subjectivity". 
actually to be a sign. ${ }^{12}$ Thus the sign has its being in a triadic relation, a relation connecting irreducibly three terms; but, while all relations are over and above the subjectivity of individual being, not all relations are triadic. The situation bears examination.

\subsubsection{The being of relations: suprasubjectivity and intersubjectivity}

The discussion of relations, if not of signs, begins in the time of Plato and Aristotle, and it is Aristotle especially who focuses the question of whether there is a mode of being properly called "relation" which is irreducible to substance with its inherent accidents. ${ }^{13}$ Now "substance", as we have just indicated, means primarily an individual subject of existence (like you or me, like fido or a pet cat, like a rose bush or an elm tree), while "accident" means first of all the inherent or identifying characteristics which set off one individual from another. So the combination of substance + accidents in this sense means quite simply SUBJECTIVITY, everything that separates one thing from another.

By contrast, RELATIONS connect or unite otherwise distinct subjectivities. "Far or near", notes Poinsot, ${ }^{14}$ "a son is in the same way the son of his father." Causality depends upon proximity; not so the pure relations which follow upon causal interactions. In the order of physical being, or 'nature' as what obtains prior to and independently of the advent of human beings, Aristotle's argument was that relations exist dependently upon the subjective characteristics of individuals, but in their being as relations they are not reducible to the subjectivities on which they depend: they are over and above those subjectivities, and precisely over and above those subjectivities as linking or joining them as otherwise separate. So one day your parents had sex, and you resulted. That activity on your parents part was thus causal, but the relation it gave rise to, linking you singularly to that man as father and that woman as mother, survived the causal activity that the relation in question presupposed but is clearly distinct from

12 See Deely 2001b; 2003.

13 The Greek texts of Aristotle on this point of relation as a mode of being irreducible to the subjectivity of individuals related are cited and discussed in the Editorial Afterword (Deely 1985: 473-479, esp. notes 112, 113, and 114.

14 Poinsot 1632: Tractatus de Signis, Second Preamble, Article 1, 85/8-12. 
(clearly, because the relation obtains long after the causal activity in question ceased).

While substance and accidents thus are subjective, relations by contrast are INTERSUBJECTIVE, between subjects. So far, moreover, we are only considering the situation of relation in the order of the physical universe independently of the existence of any animals. ${ }^{15}$ Note in particular that while there cannot be something between subjects (something "intersubjective") without that something being over and above the subjects related, ${ }^{16}$ neither can there be something between subjects in this sense of "intersubjective" unless both subjects here and now exist. Intersubjectivity presupposes subjectivity at both "ends", so to speak, of the relation.

But what about one-sided relations, to subjects that may have once existed but don't exist here and now any longer, as is the case with someone's fascination with Napoleon? And even more problematic, what are we to say about relations to what has never existed - think of poor Ponce de Leon wandering about the Florida Keys in search of the Fountain of Youth, and the like.

\subsubsection{How objects differ from things even when they are one and the same existent}

So we come to the consideration of objects which may or may not be things, but cannot be objects except as terminating a relation from a knower (whether virtually, as in physiosemiosis and phytosemiosis, however, or actually, as in zoösemiosis and anthroposemiosis). To make headway here, it becomes necessary to realize that of the three components of a relation - the supporting base of the relation in subjectivity, or fundament; the relation itself, a suprasubjective mode of being; and the terminus of the relation, that to which the relation points and with which it connects the subject "in" or upon which the relation is founded - it is the relation itself that makes the fundament to be a fundament and the terminus to be a terminus. ${ }^{17}$ Consider two triangles similar on the basis of their shape: the shape is subjective,

15 See the "Editorial AfterWord" to Poinsot's Tractatus, Deely 1985: 472-475.

16 See the wholly italicized sentence on this point at below in subsection 2.1.4 (middle of third paragraph).

17 See Deely 2007b: 119-136, esp. 125-130. 
part of the individuality of each triangle. Yet the shape of the triangle, whether considered as founding or as terminating a relation of similarity, remains unchanged in its subjectivity when the other triangular thing ceases to exist. Thus, for two triangles to be similar, there must be two triangles. But if one triangle is eliminated, the remaining triangle is no longer related thereto, nor is its unchanged shape the fundament or terminus of the no-longer-existing relation. This consideration, based on an example of a merely dyadic relationship, however, holds for the case of relations as relations, and hence also for triadic relations.

Enter animals. Animals are distinguished by having not merely a physical but also a psychological subjectivity. Psychological subjectivity is distinguished by always giving rise to relations of apprehension (both cognitive and cathectic, by the way); but these relations now are never dyadic, but always triadic, for their terminus stands as something revealed to or for the animal whose psychological state is in question. The direct terminus in the case of a triadic relation, however, is precisely a significate, an "object signified", as we say under the influence of modern philosophy - but then without realizing that the qualification "signified" here is actually redundant, for there is no other kind of objectivity. Whence, just as to every foundation or fundament corresponds a terminus, while it is the suprasubjective reality or character of the relation itself which makes a fundament as such or terminus as such, so a relation founded upon (or provenating from) psychological subjectivity will necessarily have an objective terminus (whether actually or virtually, as above noted), regardless of whether that terminus also has a subjective being or not.

So one lover looks for another after an earthquake, not knowing whether that other is alive or dead, any longer existent or not: if no longer existent, the lost one terminates the relation purely objectively; but if still alive, the lost one terminates the relation subjectively as well as objectively, the worry on the searching lover's part being not to know which (actually an all-too-normal condition among animal kind).

So we see that the essential being of relation is not necessarily intersubjectivity but much rather SUPRASUBJECTIVITY. ${ }^{18}$ And suprasubjectivity, when grounded (or, rather, founded) in psychological

18 Deely 2004c. 
subjectivity, is the cause of or reason for the difference between objects existing actually as object (whether that object be also a thing existing subjectively or intersubjectively), and things (which need not be objects in order to be). Objective relations differ from mere physical relations (such as relations between cause and effect) by involving thirds, irreducibly so; while in nature apart from animals 'thirdness' can be degenerate and virtual rather than actual. In the order of phytosemiosis actual thirdness may occur, but it is never purely objective. Purely objective reality as actual rather than virtual would seem to occur only in the world of animals, and is recognizable for what it is (thanks to "metasemiosis") only in the world of human animals - semiotic animals, as we now put it.

Now a dyadic physical relation of cause and effect, say, can as such be assimilated to an objective relation and so come to be known for what it is; but a sign relation never reduces to a cause-effect relation, ${ }^{19}$ even when/if a cause-effect dyad is subsumed into a semiosic triad, as happens, for example, when clouds become for animals signs of rain.

\subsubsection{Suprasubjectivity and objectivity in contrast to physical environment}

All right. Now we come to the lifeworld of animals, the Umwelt, or "Objective World", where things not only exist "as they are "in themselves" (bumping an empty cardboard box in the dark will not likely hurt you, whereas bumping into the point of a sharp metal object normally will), but also exist, and most importantly, "as they are 'for the animal'." Thus the Umwelt is a 'creature of experience', a tapestry woven of relation existing suprasubjectively always, but intersubjectively only in part. And the relations generically specific to the Umwelt, moreover, are always triadic - always sign-relations, even when involving dyadic relations of cause-effect interactions.

Here we discover not only that objects differ from things in being necessarily rather than contingently involved in relations of awareness, but also that "object" - far from being a mere alternative or synonym for "thing" - is simply a disguised way of saying

19 See Poinsot's Tractatus of 1632: 137 note 4. 
"something signified", or "significate" (this last being a term respecting which English dictionaries for some reason tend to be aversive). We discover also not only that all thought is in signs, but that so also is all sensation - while distinctively within cognition and irreducibly (or "irremediably") involving causal (dyadic "causeeffect") interaction between an animal's body and material bodies of the physical environment surrounding the animal's body - a matter of sign-relations. ${ }^{20}$

In the physical universe prior to life, it seems to me that we have only degenerate and virtual Thirdness, yet sufficient to move the environment through its physical causal interactions in the direction of introducing and supporting life. After the advent of life virtual thirdness becomes actual, yet remains in the order of intersubjectivities, i.e., relations as intersubjective, but three-way and not only two-way. ${ }^{21}$ With the advent of animals thirdness becomes not only virtually but actually objective as well as physical. The suprasubjectivity of relations, in contrast to and presupposed by intersubjectivity, emerges as the irreducibly essential nature of their singular being, inasmuch as intersubjective relations exist only under certain existential conditions which do not define the whole range of circumstances within which relations that are suprasubjective but yet not intersubjective can obtain. Suprasubjectivity thus proves to be presupposed by intersubjectivity, but not reducible to intersubjectivity. And thirdness, the "reality" enabled by semiosis, while normally involving sensible things, yet is itself never directly sensible. Thirdness presupposes the suprasubjective being of relation as understandable but not directly perceptible (not even when it obtains intersubjectively as well). Only human animals with their root capacity for language as Sebeok identifies it, ${ }^{22}$ traditionally termed intellectus or "understanding", ${ }^{23}$ can

20 See the Tractatus de Signis (Poinsot 1632), Book I, Question 6, esp. 205/35209/32, 211/29-212/34 and to a lesser extent 213/8-22. See further Deely 2008c: Chap. 6, on the distinction between first and second-level instrumental signs, the latter of which ("sign" as originally defined by Augustine in the late 4th century) is actually at a third level of signification respecting concepts.

21 See Krampen 1986; Deely 1986.

22 Though the point had many anticipations in Sebeok's earlier writings (e.g., 1963, 1978 inter alia), Sebeok introduced this notion of a "root sense of language" (in contrast with linguistic communication) most dramatically in his 1984 address of June 2 at Victoria College of the University of Toronto (Sebeok 1986). Thereafter it became a major theme of his thought on questions of "language". See Deely 2007a. 
come to know that there are signs (whence arises the postmodern definition of human beings as semiotic animals).

In coming to know that there are signs and that their activity semiosis - pervades nature, not only as humans are part of nature (the "semiological fallacy", as we might call it), but throughout the whole of nature, semiotic consciousness works a transforming effect upon human responsibility. Heretofore conceived primarily in cultural terms, as the responsibility each individual "as human" has for their own actions, or as the responsibility an individual has by reason of a position in society, it now becomes apparent that "human responsibility" extends to the whole of life, by reason of the fact that the consequences of human conduct affect the very conditions of survival not only for our own species but for all those other species as well with which our survival is bound up. A whole new vision of the "unity of nature" follows upon the acquisition of semiotic consciousness, wherein ethics itself is revealed to be a fundamentally semiosic phenomenon. Whence the appropriateness of the new term "semioethics" for the realization of the global impact and extent of the human exercise of responsibility in its species-specific conduct. We will return to this point in concluding this essay.

What needs to be emphasized at the present juncture is not yet the ethical implications of semiotic consciousness, but rather the manner in which the singularity of relation makes semiosis possible in the first place as an indirect influence of a future merely objective upon the present physically actual as well as partially objective (whether actually or virtually).

\subsection{The singularity of relation as enabling thirdness}

The most central point for being able to explain why signs in their distinctive action transcend nature/culture, objectivity/subjectivity, inner/outer, etc., is what can only be called the singularity of relations. This singularity consists in the indifference of relations, according to their own being as suprasubjective, to the various subjective and even intersubjective classifications or 'divisions' of being in terms of the

23 See Deely 2002. 
here-and-now reality of the physical environment. ${ }^{24}$ The Latins distinguished: being as able to exist whether or not known, they called ens reale; being which depends on being known in order to be, they called ens rationis. Being as known, then, whether ens reale or ens rationis, is the considered meaning of objective being in its full actuality as objective. Thus "reality" as experienced and known is neither ens reale nor ens rationis preclusively or exclusively, but a socially structured combination of both based initially, or "first of all", upon the bodily type of the cognitive organism.

\subsubsection{Objective world in contast to physical environment: the Umwelt}

As the doctrine of Umwelt reveals, all animal experience (including its human segment), while it consists objectively of both types of being (the stars, say, as illustrating ens reale, the city limits of Bari - or even the stars again, but now as constellations of the zodiac upon which astrologers depend! - as illustrating ens rationis), does not reduce simply to either type, but requires an interweave of both. Now experience has its being as a network of relations, what Sebeok so aptly dubbed "the semiotic web"; and the strands of these relations - the threads of the fabric of experience - reveal a pattern consisting of both mind-dependent and mind-independent objectivities together forming the public "realities" which individuals must negotiate as a whole.

But, and here is the key, relation is the only mode of being found in ens reale that can also be found with its essence whole and unchanged in the order of ens rationis; and nothing but relations constitute the order of ens rationis through and through. These are the strands of pure objectivity in that semiotic web we call "experience" (or Umwelt). True, we invent fictional "substances", such as Sherlock Holmes or Hamlet, which are indeed ens rationis. But their actual being as public objects is a pattern of relations modeled on our experience of individuals (i.e., actual substances) which are not fictional: the fictional objects in such cases are not what their models are, namely, subjective and intersubjective beings; yet the fictional

24 See the Tractatus de Signis (Poinsot 1632), Book I opening paragraphs, esp. $117 / 18-118 / 18$, and (even more specifically) $118 / 1-10$. 
objects are, as "beings patterned after" something their models as subjectivities are not - namely and specifically, relational in their own positive being. By contrast, mind-dependent relations patterned on our experiences of intersubjectivity are in their positive being what their patterns are also. Whence ens rationis as a whole, in its full extent as contrasted with ens reale, includes at bottom nothing but "beings patterned after", pure relations; while pure relations are also found intersubjectively in the order of ens reale along with subjective being (along with individuals and the inherent characteristics of individuals). Objectivity, thus, the semiotic web of "the universe as experienced", is a mixture of subjectivity and suprasubjectivity, but of the suprasubjective elements some are also intersubjective and some only suprasubjective, the whole meanwhile remaining throughout (as suprasubjective, involving subjectivities and intersubjectivities objectified but never reducing thereto) public in principle.

\subsubsection{The place and role of the Innenwelt}

We see then that experience, in its difference both from the subjectivity of the individual experiencing (even while modifying and depending upon that subjectivity) and from the subjectivities and intersubjectivities found within the world of things objectively experienced as independent of the experiencing, along with the aspects of these objects which turn out to purely objective (like the false accusation of "being a spy", when it is false; or "being a witch"; etc.), is a suprasubjective network or web of relations founded upon the psychological states (the "passiones animae") of animals, subjective qualities of the individual animal, indeed, but consisting no less in the relations thence provenant incorporating within their termini as a whole also subjective characteristics of things in the environment along with some of the relations provenant therefrom independently of the qualities of the Innenwelt in its contrast with the Umwelt. Thus the suprasubjective web of relations both between Innenwelt and Umwelt and also within the Umwelt itself are, as relations, indifferent to the circumstances that make, for example, one and the same relation at one time "real" and another time "unreal", but "objective" equally in both cases. The line is not fixed! 
Thus the suprasubjectivity of relations is the basis for the prior possibility of semiosis as an action of signs verifiable within the orders of ens reale and ens rationis alike, yes, but, far more importantly, verifiable as able to pass back and forth between the two orders with positive character as triadic relation unchanged. For triadic relations, while differing in their irreducible triadicity from (even when including) dyadic relations (of cause/effect, say), yet participate wholly and necessarily in the being definitive of every and all relation as relation, which is suprasubjectivity.

So the dinosaur bone, once actually related to a dinosaur in the order of ens reale, here and now has lost that relation, while yet continuing to exist as fundament therefor (and here and now a kind of "substance" or natural individual in its own right). And should the fossil bone fall into the hands of a trained paleontologist, the structure of the bone, itself a subjectivity, will yet be able to "tell its distinctive story", for the paleontologist on the basis or fundament of the bone will recreate as ens rationis the very same relation of bone to dinosaur which formerly (i.e., under other circumstances, the circumstances of temps perdu) was an ens reale. ${ }^{25}$ The circumstances under which any given relation is formed, in short, are what determine whether the relation itself is ens reale or ens rationis. The social construction of reality as more than bare ens reale depends on this, the basis indeed of the prior possibility of semiosis, as I said above. ${ }^{26}$

\subsubsection{Whence semiotics takes its "point of departure", finds its "proper standpoint"}

It is the being of relation, thus, relation as a singularity within being, that provides the standpoint for the doctrine of signs as transcending the divisions of subjectivity and objectivity alike, inner and outer, nature and culture. ${ }^{27}$

Very interesting is the fact that relation viewed in the exclusive perspective of ens reale turns out to be the "least" form of being, ens

25 See the Editorial Afterword to Poinsot's Tractatus, Deely 1985: 475-476, and 502 note 147.

26 And cf. Tractatus de Signis 60/26-44.

27 And it is the privilege of Poinsot to have been the first to say this in opening his Treatise on Signs, 117/28-118/18. 
minimum, the hardest to recognize at all as reale, ${ }^{28}$ because admitting of no direct sensory instance, perception giving us related things but never relations as distinguished from related things: only intellect can make that separation. Language, in the secondary sense of verbal language (or, more generally, linguistic communication), turns out to depend upon this very ability of intellect to manipulate relations as irreducible to related things. ${ }^{29}$

Moreover, when we consider that finite being is more than ens reale, and far more the higher we ascend the semiosic (or "evolutionary") ladder from nonliving matter to living matter to animals to semiotic animals to semioethic animals. Being, finite being, does not reduce to ens reale but finds its highest reality among material creatures in the objective world of human existence and life - the Umwelt (or Lebenswelt, if you want to insist on the difference between semiosic animals and semiotic animals) which does irreducibly consist of a mixture or admixture of ens rationis with ens reale, particularly in the suprasubjective character of experience as presenting to us the world not only as it is but also as it could be and even should be, if we may speak so boldly. Which of course is the point at which ethics transforms into semioethics, in the sense that the latter presupposes the recent advantage of a community of inquirers having attained to semiotic consciousness (although even incognizantly "ethics" was really "semioethics" all along).

Ens minimum at the moment of the "big bang", but already then making communication possible and semiosis virtual - such is the singularity of relation. As matter complexified, forming star systems and planets on the way to introducing life, relations become increasingly important, till finally, at the human level, they virtually make possible truly human life and personhood by enabling and constituting the difference between authenticity and inauthenticity in social affairs. Interdependency is not only real already at the level of pure ens reale; but community and personhood transcend subjectivity

28 Yet pure relation, this very ens minimum we are told (by Augustine and Aquinas), constitutes the being of each one of the three persons of the yet substantially one godhead, whose inner life consists of a communion of persons. Thus communication wherever it occurs, in the finite order or in God, consists in pure relations, so that what is least in the finite order of ens reale is greatest in the infinite being of God. Such an irony!

29 Deely 1980; 2002. 
and intersubjectivity precisely by consisting in a network of now indeed of semiosic relations. From ens minimum in the "big bang", relations ascend to ens magni momenti in the living world, and ens momentissimi magni with the achievement of semiotic consciousness, "metasemiosis", at which point they enable (semio)ethics as the final whole of human existence, recognizing its responsibility not only for its own actions but for the whole of - precisely - the things in themselves making up the reality of the physical surroundings of the planet sustaining semiotic animals as part of the biosphere as a whole.

Again we shall return to this point in our conclusion.

\section{The necessity of linguistic communication for developing any science, including the doctrine of signs}

That part of semiotics which studies signs and the action of signs specifically in the realm of human culture has been called "semiology". For several generations of thinkers in the 1960s and after, semiology was thought to be the whole of the cenoscopic science of signs; and the primary focus of these "semiologists" was usually, among cultural artifacts, linguistic communication, called "language" and conceived in terms of the conventional or "arbitrary" aspect of the signifier/ signified ("signifiant/signifie") connection, as emphasized in the work of Ferdinand de Saussure. ${ }^{30}$

The whole enterprise was largely misguided from the first, and the question I want to address is: Why would so many keen minds be led down a wrong path for so long? Peirce, outside professional circles of philosophers, was ignored by and large in the heyday of semiology, and it was not until the intervention of Sebeok in 1963, with his pioneering notion of zoösemiotics, that semiotics began to emerge not simply as an alternate name for what semiology was doing, but as the proper name for any doctrine of signs that aimed to take account of the full extent of semiosis, and not delude itself into thinking that only human beings make and make use of signs, and that only within the realm of culture properly speaking are signs truly at play as signs.

30 Saussure 1916. See Deely 2001a: Ch. 16, "Semiology: Modernity's attempt to treat the sign", 669-688. 


\subsection{Why did semiology precede semiotics when the need to study signs first became generally accepted?}

Here I want to examine, or try to outline at least, the "common sense" grounds which enabled the semiology in the misguided sense - that is to say, semiology conceived not as a part within the larger whole of semiotics, but rather as the whole study of signs and sign action complete unto itself - to flourish so widely and for so long.

The first reason the Saussurean proposal for semiology had an immediate and general appeal, I suggest, is the engrained modern philosophical habit to think in terms of dyads. Sign/signified is an embedded way of thinking of signs by the 19th and 20th centuries, and words, such as dictionary items, are, by that same period, the principal example or instance of signs: there are words, and "what they mean" — signs, with their significates (although "significate", curiously, is a term to which dictionary-makers have been highly resistant).

Missing from this equation, however, is precisely that on the basis of which words can mean what they mean: the linguistic habits of the reader of the given dictionary. If I know nothing of English and see the word "crow" in an English dictionary, although the "meaning of crow" is spelled out right there before my very eyes, the word remains "meaningless" as far as I am concerned. On the other hand, if I am a so-called "native speaker" of English (never mind that there is no more such a thing as "native speaker" than one can be "born Christian") and I see the word "crow" in an English dictionary, I have no trouble at all seeing too "what the word means". What makes the difference? Neither the sign nor the signified, but a third factor, a background factor neglected in the purview of "common sense", namely, what Peirce calls the interpretant, the "third factor" on the basis of which a sign succeeds to direct our attention to whatever it is that is signified. In this case, of course, the interpretant is the habitstructure common to speakers of English. But interpretants are not limited to human animals (though linguistic interpretants are), and indeed, as Peirce famously said, need not even be mental. (But that is another story.)

If one looks only at the sign/signified dyad within language, the relation between the two appears indeed "arbitrary", "unmotivated" by anything intrinsic to the sign. But once one adverts to the consideration that, absent the habit-structure enabling the sign to signify, the 
sign fails in its signifying function, the illusion of arbitrariness begins to fade. Of course the meaning of a word can begin in a stipulation; but a stipulation to succeed begets a habit among linguistic communicators, and unless that habit takes hold the stipulation goes aglimmering. And even the attempt at stipulation that "X shall mean Y" presupposes in the consciousness of the stipulator awareness of $Y$, an awareness which he or she must communicate to another in discourse, on the basis of those singular psychological states that we call "concepts".

In Saussure all of this is blurred, for he himself conceived of both signifier and signified as psychological realities, rather than as external things, such as written words and material things known in their externality. That in Saussure and in semiologists generally the sign is conceived of dyadically and primarily (if not exclusively) linguistically is a simple matter of fact. As to "common sense", the dyadic idea of sign and signified seems evident, so to semiology the analysis of sign in terms of signifiant/signifie appears clearly as the path to be followed.

But it comes down to this, as far as I can see. We have already considered above the question of why the study of sign activity became so late a focal point of intellectual concern in philosophy's long history, even though nothing at all is more dependent upon the action of signs than that very history! When, in the early-to-mid $20^{\text {th }}$ century, the question of the sign - what it really consists in and how does it act - finally did become a central focus of inquiry in the general intellectual culture, it took the initial form of "semiology" (i.e., a culturally centered, linguistically oriented study): in the first place, because "metasemiosis" occurs only in that sphere; and, in the second place, because apart from linguistic communication there is no entryway into that sphere as such, where alone the study of signs any signs - becomes possible.

So there is again some "common sense" grounds for thinking that language as linguistic communication - the dominant and speciesspecific means of human communication which alone makes culture as distinct from and in some ways superordinate to (though more accurately assimilative and elevative of) animal social organization is the main, if not the whole, show when it comes to the action of signs. But, as has so often proved to be the case with "common sense" (in scientific matters cenoscopic and ideoscopic alike), just as the 
revolution of the sun about the earth turned out to be a zoösemiotic illusion within anthroposemiosis, so too has the impression that linguistic communication and human culture contains the whole story of the action of signs in the universe proven to be yet another anthroposemiotic illusion.

\subsection{The linguistic approach, necessity and limitations}

To study anything, we perforce take our departure from within anthroposemiosis. Anthroposemiosis transforms the animal Umwelt, a world of objects closed to the difference between objects and things, into a Lebenswelt, an objective world wherein human understanding can avail itself of an ability to investigate "the way things are", along which path what is first discovered is the most basic difference within objectivity so far as science is concerned. That most basic difference can be described thus. On the one hand are objects of experience which reduce to our network of social interaction as grounding our experience of them (much the way that the habit of speaking English underlies our ability to recognize words in dictionaries) — such as flags signifying cities, counties, or countries; the movement of the sun around the earth; or boundaries separating counties, states, or countries; and the like. On the other hand are objects of experience which do not reduce to our experience of them, such as rocks and stars, lions and tigers, and the physical world in general.

The medieval Latins, as we saw above, called the former nonens, also "entia rationis"; the latter they called ens, also "ens reale". Being interested above all in "reality" (ens reale), and deeming that mistakenly for the whole story of "how things are", they — the Latins neither emphasized nor realized the point (at least not until, as the Latin Age drew to its end, Poinsot made the point explicit ${ }^{31}$ ) that whoever would study the being and action proper to signs required to establish a standpoint superior to, a standpoint transcending, the difference between ens (as ens reale) and nonens (as ens rationis). For while the question of signs perforce concerns a "mode of being" (the being proper to signs), that mode of being involves the singularity whereby relation alone among the modes of ens reale remains

31 Poinsot 1632: opening paragraphs of Book I, Question 1, of his Tractatus de Signis. 
unaffected in its positive structure as objectively terminating suprasubjectively regardless of changes of circumstances which make a relation as terminating one moment to have a terminus that exercises also a mind-independent existence and at another moment (often, needless to say, to the surprise of the knower) to have that same terminus but now possessed of existence only mind-dependently. The change affects only the subjective or intersubjective status of the terminus (i.e., its status in ens reale), not its objective status as significate. Not every terminus is a significate, but every significate is a terminus, regardless of its further status in the order of ens reale.

Whence, while the being of signs is indeed a question of being, it is at the same time a question of more than being, for the "being of signs" as triadic relations precisely enables an action of signs that results in nonbeing as well as being. Deception among animals depends upon it, as does outright lying among human animals; but a future at variance with the limited possibilities of any given present in "ens reale" depends upon it too - and hence the very possibility of what has heretofore been called "evolution". Concerning the irreducibility of objective world (Umwelt) to the physical environment can well be applied a formula stated by Maritain in a different context: ${ }^{32}$ "the paths of non-being, once one has, by a kind of inverted intuition, become conscious of it and of its formidable role in reality, are as difficult as those of being". 33 It took Sebeok's assimilation of the Umwelttheorie of Jakob von Uexküll ${ }^{34}$ for semioticians fully to recognize that the objective world of animal experience is, in every case, a species-specific world composed of an interweave of minddependent and mind-independent relations in an ever-changing proportion and mixture.

32 Maritain 1966: 32.

33 Precisely here is the place where semiotics assimilates the ethical insights of Emmanuel Levinas (e.g., 1974) that, in Petrilli's summary (2008: 203), "the being of social communication has an otherwise than being", where 'being' means ens reale. and 'otherwise than being' means above all the element of ens rationis essential to the constitution of every Umwelt in its difference from the physical environment.

34 Cf. Deely 2004a. 


\subsubsection{What language as semiosis consists in}

So, to "begin at the beginning", we perforce take our departure for the study of signs (as for anything else) from within anthroposemiosis; but insofar as anthroposemiosis is semiosis, our first question equally perforce has to bear on what semiosis is, for the linguistic communication upon which human animals so crucially and species-specifically rely is not an autonomous realm, as Analytic philosophers of the early and mid-20th century deluded their successors into thinking, but a question of one type of sign among (many) other types, including types which linguistic communication presupposes and depends upon. ${ }^{35}$ So even if we wish and in some sense must begin with linguistic signs, among the first questions to be faced is "the place of linguistic signs among signs in general", as Todorov so well noted. ${ }^{36}$

Anthroposemiosis is semiosis first of all, but linguistic communication too "first of all", if by "first of all" we mean not merely the 'logically prior' but the species-specifically distinctive. The problem is to balance these two senses of "first". Let us, then, start where we must in order to communicate with others at the level of metasemiosis, with language.

Even though language is the indispensable entry and portal to full participation in any Umwelt as species-specifically human (that is to say, as consisting of a cultural environment capable of supporting inquiry both cœnoscopic and ideoscopic into the nature of things), to make of linguistic analysis the very substance of philosophy was among the final delusions of modernity, for the reasons first suggested by Todorov ${ }^{37}$ and spelled out at length by Deely (2006a), namely, that language itself is, for all its grandeur and centrality to human identity, life, and culture, but one system of signs among others, one which achieves autonomy only relatively and while remaining dependent in the main on the elements of zoösemiosis without which even the highest achievements of speculative discourse in science and philosophy would implode.

What makes language in the sense of linguistic communication possible in the first place is the distinctive capacity of human understanding to objectify realities which cannot be reduced to

35 Deely 1980.

36 Todorov 1978: 40. See Deely 2006a.

37 Todorov 1978: 40. 
sensory instantiation. In short, the same ability which enables human animals to wonder whether God exists is the ability which enables them to manipulate relations in their difference from related things, and it is this ability to handle cognitively relations in their difference from related things that make possible stipulations of meaning exapting the biologically underdetermined human Innenwelt to express new potential arrangements which are and must often ${ }^{38}$ remain invisible to direct sense perception of their "reality". Communication takes place in the realm of related things; but linguistic communication bears more on the relations themselves than on the things often precisely in order to introduce arrangements different than what sense can directly manifest.

\subsubsection{Demonstrating the inadequacy of linguistic analysis as an autonomous approach to philosophical questions}

The development of semiotics as the doctrine of signs, that is to say, as a cœnoscopic rather than an ideoscopic science, ${ }^{39}$ gives us one of the clearest reminders (if one still be needed) that, as far as science and philosophy are concerned in their proper dimensions as investigative of realities and explicative of the results of those investigations, the "meaning of a word" cannot possibly be either a simple stipulation of "what I want it to mean" (what we might call "the Humpty-Dumpty fallacy") or an exposure of its "use in a language" ("the Wittgenstein fallacy"); for both stipulation and established customs of use are at the service of something else, to wit, the very nature of the object of the investigation and the determination through that investigation of what in the object belongs to it independently of its relations to us, and what belongs to it precisely in consequence of the network of relations

38 An example of an exception would be would be an hypothesis concerning the existence of some previously unexperienced physical reality, the way that the planet Neptune was originally proposed theoretically and then actually observed by human eye. By contrast, a new system of government can be "put into place", but that system cannot be directly observed except in its "parts" - people and buildings - assigned to official status within the in-itself invisible system consisting "in itself" in pure relations. Dogs can bite Presidents, but not as Presidents! 39 Bentham 1816 (esp. Appendix No. IV, the "Essay on Nomenclature and Classification", 1962 [1816]: 63-128); Peirce 1905: CP 8.199; Deely 2008c throughout. 
mind-dependent as well as mind-independent into which it perforce enters as object - something existing at least in part as cognized or known - in contrast to the being proper to "things" as what are what they are whether or not they are a part of any finite consciousness.

Consider what a dead-end results when we take the linguistic expression or term "sign" as a dictionary item and make that ("its use in a language") as the point of departure as such for would-be semiotic analysis. Nothing in the nearly four half-page columns on p. 2820 of our 1971 edition of the Oxford English Dictionary (the latest electronic edition does not improve on this point) suggests anything like what has become common knowledge among semioticians today - thanks not to dictionaries but to the work of Poinsot and, more recently, Peirce in establishing the purely relational mode of being proper to signs in their distinctive being.

"In its genuine form", Peirce advises us, "Thirdness is the triadic relation existing between a sign, its object, and the interpreting thought, itself a sign, considered as constituting the mode of being of a sign."

Indeed, we now realize that what the dictionaries heretofore all but exclusively treat under the entry "sign" are what semiotics today recognizes rather as but the vehicle occupying that one of the three positions involved in signification which presents something other than itself to or for some third. "Being a sign" in the dictionary sense of sign-vehicle is in itself not a sign at all, inasmuch as what occupies the foreground position in question within a triadic relation, namely, the representamen (to use Peirce's felicitous coinage) can on other occasions and in other contexts occupy instead either of the two other positions united in the sign's relation, namely, that of the significate (or "object signified", as we say redundantly) or that of the interpretant, the 'third' to or for whom the object signified is signified by the sign (vehicle).

But remove the triadic relation, the being formal and proper to the sign, and all three - representamen, significate, and interpretant either cease to exist (insofar as they are purely objective realities) or at least fall back into the bare existence of things which have no necessary relation here and now to a finite knower in order to be as

40 Peirce 1904: CP 8.332, bold face added; Poinsot 1632: 1.3 155/25-29, again bold added: the irreducibly triadic relation "is the proper and formale rationale of a sign". 
elements of the physical surroundings. Under such circumstances, nonetheless, where there may be no sign actually (i.e., fully as genuine Thirdness), yet there remains the representamen active as a sign virtually, as we will see both Poinsot and Peirce to say, e.g.. ${ }^{41}$

while no Representamen actually functions as such until it actually determines an Interpretant, yet it becomes a Representamen as soon as it is fully capable of doing this; and its Representative Quality is not necessarily dependent upon its ever actually determining an Interpretant, nor even upon its actually having an Object.

In such a case, therefore, the "being of the sign" is a triadic relation only virtually rather than actually, and that being is, at least for the moment, and under the circumstances reduced (as it were) to such being as the representamen has in its interaction with the physical surroundings as one "thing" among other "things". As Peirce puts it, ${ }^{42}$ the triadic relation itself, therefore, must, as virtual rather than actual,

41 Peirce c.1902/1903: CP 2.275; Poinsot 1632: 126/3-22 makes this same point as follows: "[...] sufficit virtualiter esse signum, ut actu significet. Et instatur manifeste in hac: B actu causat et producit effectum, ergo actu in re est causa; nam ipsa causa non existens in se, per virtutem a se relictam causat et formaliter causat, quia effectus tunc formaliter producitur. Sic existente signo et significatione virtuali formaliter ducit potentiam ad signatum, et tamen formaliter non est signum, sed virtualiter et fundamentaliter. Cum enim maneat ratio movendi potentiam, quod fit per signum, in quantum repraesentativum est, etiamsi non maneat relatio substitutionis ad signatum, potest exercere functiones substituentis sine relatione, sicut servus vel minister potest exercere operationes sui ministerii etiam mortuo domino, ad quem dicit relationem, et in qua formaliter consistit ratio servi et ministri." - "[...] it suffices to be a sign virtually in order to signify in act. This can be readily seen in an example: $X$ in act causes and produces an effect, therefore it is in act really a cause; for when the cause in question no longer exists in itself, through the virtuality or efficacy it leaves behind, it causes and causes formally, because the effect is then formally produced. Just so, when a sign exists and by a virtual signification formally leads the mind to something signified [which no longer exists in fact], it is nevertheless not a sign formally, but virtually and fundamentally. For since the rationale of moving or stimulating the mind remains, which comes about through the sign insofar as it is something representative, even if the relation of substitution for the signified does not remain, the sign is able to exercise the functions of substituting without the relation, just as a servant or minister can perform the operations of his ministry even when the master, to whom he bespeaks a relation, and in which relation the rationale of servant and minister formally consists, has died."

42 Peirce 1903: CP 1.542. 
"consist in a power of the representamen to determine some interprettant to being a representamen of the same object"; ${ }^{33}$ or, as Poinsot put it, "it suffices to be a sign virtually in order to signify in act.",44

Of course, as semiotics advances and becomes familiar to more and more individuals, larger and larger groups within the various lifeworlds of species-specifically human culture, the dictionaries themselves will change and reflect new usages of "semiotics and its congeners" which will indeed, at that future time, give "linguistic philosophers" a sufficient purchase to ply their wit and analytical cleverness in ways that have ceased to be semiotically obtuse (not at all because of their "linguistic method", note, but simply by virtue of the inevitable evolution of the language itself "in use". But we are not at that future point, far from it; and what we need to do rather is give creative linguistic expression de novo to the results of investigations of the action of signs precisely as revealing the being of signs to human understanding. This will involve, to be sure, stipulations some new ways of speaking. And it will involve too taking account of established customs of "use in the language". But it perforce goes beyond both (as does any properly philosophical analysis).

43 Peirce is speaking of "degenerate cases" from the standpoint of genuine Thirdness; but from the standpoint we are considering we might well call them "pregenerate" cases. Cf. Deely 1994: Ch. 7.

Poinsot, of course, had no idea whatever of the universe as an evolutionary development, yet his notion of semiosis points precisely in that direction once the myth of the celestial spheres has been exposed, which makes his remarks on the point at hand all the more interesting - Poinsot 1632: Treatise on Signs, Book I, Question 1,126/3-22: "it suffices to be a sign virtually in order to signify in act. This can be readily seen in an example: $X$ in act causes and produces an effect, therefore it is in act really a cause; for when the cause in question no longer exists in itself, through the virtuality or efficacy it leaves behind, it causes and causes formally, because the effect is then formally produced. Just so, when a sign [as representamen] exists and by a virtual signification formally leads the mind to something signified [which no longer exists in fact], it is nevertheless not a sign formally, but virtually and fundamentally. For since the rationale of moving or stimulating the mind remains, which comes about through the sign insofar as it is something representative, even if the relation of substitution for the signified does not remain, the sign is able to exercise the functions of substituting without the relation, just as a servant or minister can perform the operations of his ministry even when the master, to whom he bespeaks a relation, and in which relation the rationale of servant and minister formally consists, has died." 
So, just as we have already noted, the task simply does not and cannot reduce to either or both of those two functions - stipulation and use - upon which "linguistic philosophy" as such (the "linguistic turn" of Analytic philosophy after the later Wittgenstein) completely depends. For the question is not that which the dictionary is designed to answer ("What is a sign viewed in terms of established usage?") but what is a sign in its proper being. Not only is the question of what the dictionary is designed to answer not yet the question that semiotics seeks to answer, but that very question of what the dictionary has to say is quite beside the point inasmuch as the semiotician, as Peirce put it, ${ }^{45}$ is rather "in the situation of a zoölogist who wants to know what ought to be the meaning of 'fish' in order to make fishes one of the great classes of vertebrates". If it were up to the linguistic philosophers, we would not to this day have been able to learn that whales are not a species of fish; nor would we have learned that signs in their proper being cannot be seen with the eye!

\section{In search of the broadest sense of sign}

"Taking sign in its broadest sense," Peirce advises, ${ }^{46}$ "its interpretant is not necessarily a sign"; and here our late-modern master of the transition to postmodernity begins to grope:

we may take a sign in so broad a sense that the interpretant of it is not a thought, but an action or experience, or we may even so enlarge the meaning of sign that its interpretant is a mere quality of feeling. A Third is something which brings a First into relation to a Second. A sign is a sort of Third. How shall we characterize it?

Concepts, Peirce notes (1904 and elsewhere), if we go back to the Latins, have more than sufficiently been established as interpretants which are necessarily signs. ${ }^{47}$ But what of those interpretants which are not necessarily themselves signs, or even "something mental"? What of the action of signs among plants, for example, where animal

45 Peirce 1904: 8.332.

46 Ibid.

47 See Doyle 1985, 2001, Deely 2007b: Ch. 12. 
consciousness is not directly involved? ${ }^{48}$ But Peirce goes even further than this, the extension of the action of signs to the whole of the lifeworld. "Who", he asks, "is the utterer of signs of the weather?"

But he goes in this same manuscript even further still: there are cases, he tells us, ${ }^{50}$ where "there must be a sign without an utterer and a sign without an interpreter".

In any such case, carefully note, Peirce is not speaking of the sign in its full sense as a triadic relation provenating from a representamen but rather of some version of "degenerate Thirdness", as he calls it, which is a representamen as such, i.e., a sign-vehicle, a 'reality' from which a triadic relation would provenate did but circumstances permit. For "if a sign has no interpreter", he remarks, ${ }^{51}$ "its interpretant is a 'would be', i.e., is what it would determine in the interpreter if there were one."

\subsection{Why Sebeok's final view of semiosis as co-extensive with life is not broad enough}

This brings me to the nexus, the crucial node, of the musement I am placing before you with this essay: when Sebeok notes ${ }^{52}$ that "life modifies the universe to meet its needs, and accomplishes this by means of sign action", while feeling at the same time "strongly drawn to Wheeler's suggestion ${ }^{53}$ that the fundamental physical constants, the nuclear and cosmological parameters, and others, are constrained by the unbudging requirement that life evolve", is he not suggesting without realizing it that the development of the physical universe prior to the advent of life was itself a product of semiosis, even if that prior

\footnotetext{
48 The realization that there is an action of signs among plants, "phytosemiosis", is rightly regarded as one of the main achievements of the later 20th century, and indeed the achievement which made the contemporary notion of biosemiotics possible: no life without the action of signs.

Peirce c.1907: Ms 318, ISP pages 205-206, a part of 318 that remains unpublished as of 2008 (see gloss on Peirce c. 1907 entry in the References at the end of this essay).

50 Peirce c.1907: EP 2.404.

51 Peirce 1907: EP 2.409

52 Sebeok 1985a: 21

53 Cf. Wheeler 1977; also Whitaker 1988, and Barrow et al. 1988.
} 
development, as Peirce suggested, ${ }^{54}$ "cannot be fully revealed or brought to light by any study of the sign alone, as such. Knowledge of it must come from some previous or collateral source."

In short, even if we accept Sebeok's proposition that there is no life without the action of signs, we have still to ask if the converse of this proposition, "no signs without life", is also true? Sebeok, the principal architect of semiotics as overtaking and absorbing semiology as but a part of the doctrine of signs, was inclined so to think.

But we have to realize that Peirce had a still broader view, and Poinsot in this same line of thinking gave concrete indications of a philosophical nature ${ }^{55}$ to suggest that while indeed semiosis is essential for living things to maintain themselves as living, there is also reason to consider that semiosis is essential to living things not only in their present and actual existence, as Sebeok recognized, but also to the bringing about within the physical universe of the initial conditions which made life first proximately possible and then actual - at which point semiosis passes from all 'grades of degeneracy' (or 'pregeneracy') to reveal its full and genuine form in the veritable conflagration of sign activity drawing ever more and more complex living systems into reality as nature begins its climb, certainly on this planet (as all but certainly on planets elsewhere) toward that unique form of life which not only makes use of signs but is able to recognize that there are signs: the life of the semiotic animal.

For with the human being emerges a consciousness which will bring with it, as we have seen, and for the first time in the finite universe, responsibility: responsibility for the future of the species of animal within which that singular consciousness emerges, but a responsibility which turns out to extend in principle to every other animal species as well, because the responsibility is rooted in a form of knowledge which alone is capable of envisioning the requirements of the biosphere as a planetary phenomenon and so of taking steps to bring civilization and culture into line with the requirements which, unless met, will destroy Gaia - the planetary whole of biosemioses upon which the flourishing of even human life depends.

54 Peirce c.1907: EP 2.404

55 Deely 1994: Ch. 7. 


\subsection{Semiosis as cause no less than condition of life}

I want to muse out loud, then, pace Sebeok, that the true interpretation of the formula or maxim "no life without signs" is the one that makes the action of signs coextensive with the living world, indeed, as biosemiotics has increasingly demonstrated, but avoids the possible error (the "quasi-fallacy", as we might put it) ${ }^{56}$ of making the action of signs purely and simply a function of life. The most extreme form of the assertion that semiosis is a function only of life is no doubt witnessed in Short's blunder making the purposive behavior of animal life essential to the function of signs as signs. ${ }^{57}$ But we have to wonder if even the broader and moderate assertion that life-science is coextensive with sign-science is not already a quasi-error. The text which I take as a focus for my play of musement on this particular occasion is the following one from Peirce:

Finally, as what anything really is, is what it may finally come to be known to be in the ideal state of complete information, so that reality depends on the ultimate decision of the community; so thought is what it is, only by virtue of its addressing a future thought which is in its value as thought identical with it, though more developed. In this way, the existence of thought now depends on what is to be hereafter; so that it has only a potential existence, dependent on the future thought of the community. (Peirce 1904: CP 5.316.)

No doubt my musement here presupposes some form of the so-called "anthropic principle", according to which the universe is not indifferent to the existence of semiotic animals, but develops in such a way and along such lines as to become aware of itself precisely by bringing about the conditions necessary to sustain such a form of life. ${ }^{58}$ This idea is new in the context of our understanding of the universe as a semiosic and evolutionary whole; but even in preevolutionary views of the physical world, the orientation of nature to

56 Recalling Sebeok 1985a: 20.

57 Short 2007, passim; documented in Deely 2008b.

58 "Incidentally," Sebeok reported (1985a: 21), "Bense 1984 came to the identical conclusion that the Anthropic Principle is a semiotic principle," although Tom confessed himself "at a loss to follow his dense yet exiguous argumentation." 
the sustenance of life in its highest semiosic form was already a thesis explicitly held by Thomas Aquinas ${ }^{59}$ among others.

What is new in our consideration is the light that the realization of how signs work in the universe - semiosis - throws upon the thesis that the material universe tends so to arrange itself as to bring about living things, and living things in turn tend to develop in the direction of semiotic animals. For the action of signs follows upon the being of signs; and the being proper to signs in their full and genuine form as triadic relations is not as such the substantial form of a living creature. Far from it. The being constitutive of signs in their proper being is a part of that tenuous network of relations without which such substances - living things - could neither emerge nor survive in the first place.

\subsection{The crucial point over which Peirce and much semiotic development after him stumbled: the causality proper to signs as signs}

Animals act with purpose. For that matter, so do plants, and even inorganic substances in their own way. "Purpose" applied to nature names an intrinsic finality which is observable in the behavior of "natural units" - that is to say, actual individuals in the sense Aristotle termed "substances". Many things that appear to "common sense" as "individuals" are indeed not individuals in the sense of units of nature. But whenever we succeed to isolate natural units, substances natural in the strict Aristotelian sense of "individuals", we always find that they act in determinate ways in given circumstances, and that these "determinate ways" lead to determinate developments and outcomes in the course of which chance can intervene to alter the outcome, but not to change the fact that every finite interaction of individuals in nature is involved with tendencies to outcomes which accumulate over time, and even incorporate the unexpectancies of chance interventions to move the universe as a whole to what we may perhaps describe as a "growth in time".

59 Aquinas i.1259/65: Summa contra gentiles 3; developed in Deely 1969. 


\subsubsection{The action of signs vis-à-vis finality}

So far we have described what might best be termed a "Darwinian universe", one that develops mainly by chance, diverting development away from status quo, yes, but purely "vis à tergo" ("force from behind") style. But notice that Waddington was alone right among the neo-Darwinians with his insistence on the role of the "epigenetic system" in its contrast to the "genetic system" as an "anti-chance factor", one in addition to, or alongside, natural selection as an antichance factor. ${ }^{60}$ It is this second antichance factor in particular, along with chance, that opens the door to semiosis as an influence of the future (a "vis à prospecto"); for chance and finality alike entangle with the "information concerning possibility" that semiosis manifests or makes available, with the result of bringing about imprevisible states of affairs which (so to speak) conspire in the collectivity to first make the universe suitable for life, then to make living things actually occur and develop in the direction that will eventually allow the sign to become aware of itself through the reflection, the "metasemiosis", of semiotic animals. ${ }^{61}$

Thus purpose permeates nature, but through the interactions of individuals and collectivities of individuals. The action of signs is something else again, everywhere entangled with purposes, as also with chance, indeed, but distinct from both of them. When Peirce opined c. $1902^{62}$ that "all causation divides into two grand branches, the efficient, or forceful", that is to say, causality in the order of brute Secondness, "and the ideal, or final" his addition at this point equating "final" with "ideal" proved to be, not so much for himself as for his later followers, a near-fatal misstep; for final causality occurs in the entitative realm of subjectivity primarily and first of all, while ideal causality is over and above that order, actual in the objective world or Umwelt of animals, but virtual already in the inorganic realm as

physiosemiosis as also in the organic world prior to animal awareness as phytosemiosis.

60 See Waddington 1960, 1961; Deely 1969.

61 Deely 2008a.

62 Peirce c.1902: CP 1.211. 


\subsubsection{The crucial gap in Peirce's Collected Papers}

Among the materials not to be found in the Collected Papers, where Peirce identifies the causality proper to signs as "ideal, or final causality", are the parts of his manuscript 283 of 1906 where Peirce qualifies his earlier equation of final with ideal causality as perhaps having been "a too wide concept" which "will do no harm whatever, provided that a careful division of it be made", whereupon he proceeds to show that the "careful division" in need of being made is precisely the later Scholastic division between final causality, whether intrinsic (teleonomy) or extrinsic (such as the purposive behavior of organisms), and formal causality as extrinsic to a subject, that is to say, as "objective", whether actually or only virtually.

The distinctions involved here take us well beyond the "four causes" - efficient, material, formal, and final - identified by Aristotle as essential to the analysis and understanding of physical change in the environment. Whereas Aristotle conceived his scheme of causes in relation above all to the physical environment of changeable being, the Latins not only took over this scheme in their philosophia naturalis, but extended its application to the world of culture and the understanding of discourse.$^{63}$ In order to achieve this extension of causality to include the world of culture as well as that of nature as independent of culture, they found it necessary to distinguish both formal cause and final cause as extrinsic as well as intrinsic; ${ }^{64}$ and formal cause as extrinsic they found it necessary to further subdivide between exemplary (the causality at work in art), and specifi-

63 This full extent of the Latin analysis of causality in original texts is laid out in Deely 1992: 66n5, and further discussed in Deely 1994: Ch. 6 and Deely 2001a. In this last work, consult the Index entry CAUSALITY (p. 864), and Chap. 10, esp. pp. 472-479). The loci for Poinsot's own complete analyses of causality are set out in the two notes and following.

64 The most reliable synoptic summaries of late Latin analyses of causality are laid out found in Poinsot's Cursus Philosophicus Thomisticus of 1631-1635. For efficient, material, intrinsic formal, and extrinsic exemplary formal causality, consult Poinsot 1633: Questions 10-13, 197a11-287b43 - where, however, extrinsic specificative formal causality ('objective causality'), the causality proper to signs, is mentioned only in response to an objection confusing it with exemplary causality $245 \mathrm{a} 24-43,247 \mathrm{a} 7-14$. See not following for the loci of his direct discussions of objective (extrinsic formal specificative) causality, the causality distinctive of semiosis as the action of signs. 
cative (which they also termed 'objective'). ${ }^{65}$ This last subdistinction, i.e., of formal causality as extrinsic to a subject but specificative of a role or function to be performed, they were then able to demonstrate as the precise sort of causality needed to explain the agere that follows upon the esse of signs. Poinsot's analysis on this point, "Whether to signify, formally considered, is to cause something in the order of productive causality?", 66 stands to this day as the most historically authoritative discussion of this question in the literature of semiotics.

\subsubsection{Signs as vehicles versus signs as signs}

It is well to remember that the original notion of sign in general, as Augustine introduced it, was the common notion of sign as some material object which represents something other than itself in the eye of the beholder. Only gradually did the Latins realize that there are signs which are not objects first of all, namely, psychological states on the basis of which objects are presented interpreted as this or that. And only later still did they come to realize, as would Peirce after them, that what made material objects or psychological states alike be signs in the first place was their occupation of the foreground position of representing another within a triadic relation, whereupon Peirce concluded that what are commonly called signs are in reality but the vehicles of signification, while signs in their proper being are rather the triadic relations themselves without which signs in the common sense (something that can be seen or heard or touched) would not be signs at all. Signs in the common sense, the vehicles conveying a signification, he proposed to term rather representamens, in contrast to the triadic relation itself which functions as a pure medium of communication, and nothing more.

Thus there is an important difference between a sign in the common sense of a vehicle, and a sign in the strict and technical sense

65 The direct discussion of formal causality as extrinsic specification is to be found in Poinsot 1632, as follows: Q. 17, Arts. 5-7, 595b25-608b7; Q. 21, Arts. 4 and 5, 670a11-693a31; Q. 22, Arts. 1-4, 693a34-715a21; and further in his biological treatises of 1635 , in the context of the discussion of cognitive organisms: Q. 6., Arts. 2-4, 177b1-198a16; Q. 8, Art. 4, 265b1-271b20; Q. 10, Arts. 1-5, 295b1-339a45; Q. 11, Arts. 1 and 2, 344b1-366b34.

66 See Question 5, Book I, of Poinsot's Tractatus de Signis of 1632. 
of the triadic relation under which that vehicle stands as means of conveyance. The former Peirce calls "the body of the sign", 67 or its "requisite vehicle"; ${ }^{68}$ the latter he calls "the meaning of the sign". For the vehicle or 'body' of a signification, as a subjective reality in its own right (even when it is only a characteristic of an individual, as in the case of a psychological state), functions more broadly in its own right than its bare function within a given semiosis. Within the semiosis, it is the triadic relation and only the triadic relation which provides the 'meaning' of the sign. Yet this meaning can be sustained or conveyed by various vehicles, for which reason Peirce contrasts the sign in its "body" to the sign in its proper being as triadic relation as comparatively "inessential", inasmuch as the content of the communication depends upon the latter and only incidentally upon the former. ${ }^{69}$ Thus we note the crucial distinction between a sign-vehicle and a sign-vehicle: A sign as sign is a medium of communication - that and that only, existing as such (being a relation) suprasubjectively. A sign-vehicle is a medium of communication, indeed that, but not necessarily only that, for the reason that it has a subjective being along with the suprasubjective being it conveys objectively.

With this distinction in mind, see how Peirce moves toward Poinsot's demonstration that the causality proper to signs is as a specificative extrinsic formal causality:

A medium of communication is something, $A$, which being acted upon by something else, $N$, in its turn acts upon something, $I$, in a manner involving its determination by $N$, so that $I$ shall thereby, through $A$ and only through $A$, be acted upon by $N$. We may purposely select a somewhat imperfect example. Namely, one animal, say, a mosquito, is acted upon by the entity of a zymotic disease, and in its turn acts upon another animal, to which it communicates the fever. The reason that this example is not perfect is that the active medium is in some measure of the nature of a vehicle, which differs from a medium of communication in acting upon the transported object and determining it to a changed location, where, without further interposition of the vehicle, it acts upon, or is acted upon by, the object to which it is conveyed. A sign, on the other hand, just in so far as it fulfills the function of a sign, and none other, perfectly conforms to the definition of a medium of communication. It is

67 E.g., Peirce 1903: CP 2.222.

68 Peirce c.1902: CP 2.111.

69 E.g., Peirce c.1906a: CP 4.6: "One selfsame thought may be carried upon the vehicle of English, German, Greek, or Gaelic; in diagrams, or in equations, or in graphs: all these are but so many skins of the onion, its inessential accidents". 
determined by the object, but in no other respect than goes to enable it to act upon the interpreting quasi-mind; and the more perfectly it fulfills its function as a sign, the less effect it has [...] other than that of determining it as if the object itself had acted upon it. Thus, after an ordinary conversation, a wonderfully perfect kind of sign-functioning, one knows what information or suggestion has been conveyed, but will be utterly unable to say in what words it was conveyed, and often will think it was conveyed in words, when in fact it was only conveyed in tones or facial expressions. (Peirce 1906: EP 2.391) ${ }^{70}$

So, while animals, for example, have purpose, signs as signs do not. Signs convey what they convey, make of it what you can or will. The smoke of the volcano, does it signify only burning, or also the anger of the gods? Purpose is normally but always introduced into semiosis from without, from the entanglement of signs with the behavior of substances which are not but in spite of themselves become signs. Thus a given representamen as sign-vehicle, "just insofar as it fulfills the function of sign and no other function besides", represents an ideal limit seldom or never reached in semioses actually occurring among interacting natural individuals and groups of individuals. A sign as vehicle of communication is not a mosquito as transmitter of disease (or a vaccination shot as preventive of disease), though accidentally, by reason of the vehicle's properties as subjective in its own right having an existence which is more than can be reduced to its formal role as sign, it can become like a mosquito (or a vaccine)! But that is per accidens to the material status of the vehicle, not per se to its formal status as conveying the action of sign as sign.

\subsubsection{Recognizing the "ideal limit" in vehicles of communication}

Thus, a sign, in the sense of sign-vehicle, risks or may risk to be mistaken for the material characteristics and causal capacities of that particular bodily type (cf. Deely 2003). So we must be quite careful and explicit in using the term "vehicle" or "sign-vehicle" for the representamen in semiosis that we are using the term only in the precise sense of fundament of the relation of signification grounded in

70 As André DeTienne put the matter to me in an email exchange of Sept. 20, 2007: "A good sign disappears in the very moment that an information gets effectively conveyed". 
the object as presented formally to, not as materially acting upon, the interpretant - even though the sign-vehicle as, say, a material body in its own right, exercises other modes of causality along with and independently of that causality definitive of semiosis precisely as such. By contrast with "sign" in the sense of the material or even psychological vehicle embodying the sign-relation as fundament, a sign formally considered "just in so far as it fulfills the function of a sign and none other, perfectly conforms to the definition of a medium of communication", thus (continuing Peirce from the 1906 MS 283):

It is determined by the object, but in no other respect than goes to enable it [that object which has determined the sign] to act upon the interpreting quasimind [the Interpretant] other than that of determining it as if the object itself had acted upon it. ${ }^{71}$

The sign as a sign is not a vehicle which modifies what it conveys, but rather one which purely conveys: and so it acts in the order of a formal cause rather than an efficient cause, yet not as an intrinsic formal cause, but rather as an extrinsic formal cause specifying its interpretant from without and indirectly, that is to say, via the sign.

If we wish to emphasize this formal element as what is essential to the sign as vehicle of communication, then, the sign:

may be defined as a Medium for the communication of a Form. It is not logically necessary that anything possessing consciousness, that is, feeling of

71 Note that, in Peirce's own text, we are dealing with a matter of formal, not efficient, causality when it comes to the question of how signs actually accomplish communication in bringing about their "proper significate outcome". I emphasize this, because it gives us the means from within Peirce's writings to correct the actual main flaw in his semiotic, namely, the conflation of all ideal causality with final causality. In fact, it is just this flaw, uncorrected, which steers Short off the path to think that, if signs require final causality in the sense of purpose, this semiosis can only be fulfilled in the behavior of animals. Peirce did not think that final causality was extrinsically involved in semiosis, but inherently involved (because he saw it as the only alternative within ideal causality in contrast with efficiency), not by importation as Short proposes. But in Peirce's case this was a matter of confusion, and a confusion in the process of being overcome, resulting from an oversimplified notion - I am speaking here only concerning semiosis, not of the broader question of 'natural classes' - of ideal causality so far as concerns the action proper to signs. It is a pity that this was one aspect of the later Latin writings he did not come across in his many consultations. 
the peculiar common quality of all our feeling, should be concerned. But it is necessary that there should be two, if not three, QUASI-MINDS, meaning things capable of varied determination as to forms of the kind communicated. [Peirce 1906a: MS793 from EP 2.544n22.]

Peirce then repeats, with the term "medium" substituted for "vehicle", the triadic formula which has been familiar and extensively discussed among the Latins from the late 4th century of Augustine's work to the early 17th work of Poinsot, but which Short's Analytic crowd never considered or heard of before the 1930s:

As a MEDIUM, the Sign is essentially in a triadic relation, to its Object which determines it, and to its Interpretant which it determines. In its relation to the Object, the Sign is PASSIVE; that is to say, its correspondence to the Object is brought about by an effect upon the Sign, the Object remaining unaffected. On the other hand, in its relation to the Interpretant the Sign is ACTIVE, determining the Interpretant without being itself thereby affected.

Now we are told the whole point of the reformulation (I add the SMALL CAPITALS for emphasis of the central point):

But at this point certain distinctions are called for. That which is communicated from the Object through the Sign to the Interpretant is a FORM. It is not a singular thing; for if a singular thing were first in the Object and afterward in the interpretant outside the Object, it must thereby cease to be in the Object. The FORM that is communicated does not necessarily cease to be in one thing when it comes to be in a different thing, because its being is a being of the predicate. The Being of a FORM consists in the truth of a conditional proposition. Under given circumstances, something would be true. The FORM is in the Object, entitatively we may say, meaning that that conditional relation, or following of consequent upon reason, which constitutes the Form, is literally true of the Object. In the Sign the FORM may or may not be embodied entitatively, but it must be embodied representatively, that is, in respect to the FORM COMMUNICATED, the Sign produces upon the Interpretant an effect similar to that which the Object itself would under favorable circumstances.

This may well be the most "scholastic" passage that Peirce ever penned. ${ }^{72}$ Certainly it is one of the most scholastic passages, for

72 Houser et al. (EP 2.544n22) emphasize that "the conception of a sign as a Medium for communication becomes very prominent in Peirce's 1906 writings." I shall argue that this importance is itself a sign that Peirce was moving toward the 
anyone who actually knows something of the scholastic development of semiotic among the Latins will instantly recognize in Peirce's entitative/representative distinction the clear echo of Poinsot, Scotus, or Aquinas distinguishing between esse entitativum and esse intentionale. The above remarks of Peirce on Form as extrinsically causing the sign respecting its object to produce or be inclined to produce an Interpretant, when viewed against a greater familiarity with the late Latin semiotic development than even Peirce had attained, show that in the late development of his semiotic Peirce was himself moving beyond the mistaken idea that teleology is as such (i.e., as 'final causality') proper to semiosis in its own right, and toward the idea that specificative extrinsic formal causality is rather the causality proper to the action of signs, as will become clearer in what follows.

\subsubsection{Tracing the error to its "common sense" source}

But at least Peirce makes clear from where (besides from incomplete readings of his own writings!) arises the error of thinking — the source of the contrary to fact proposition - that final causality is the causality proper to semiosis. It is the point over which Peirce himself, and those who prefer being epigones to being semioticians in their own right with a responsibility for knowledge of sources in the development of their subject matter, seriously stumbled:

a sign is ordinarily understood as an implement of intercommunication; and the essence of an implement lies in its function, that is, in its purpose together with the general idea [...] of the means of attaining that purpose. (Peirce 1906: EP 2.389.)

Thus a stop sign has the purpose of controlling traffic. But that purpose belongs to the stop sign from outside its being as sign. As a

Scholastic recognition that what he called "ideal" causality involved a kind of formal causality (extrinsic formal causality) and not simply final causality: consult the references in notes 63-65 above. Certainly from this point of view the year 1906 is much more important than Short's identification of 1902 (60), "when the idea of final causation assumed explicit central importance in Peirce's philosophy."

73 In particular, see notes 77 and 78 , respectively, below. 
sign, it can only formally represent to trafficants where their vehicle should halt movement; but the sign cannot bring about such a halt, nor does it itself intend to do so. The intention belongs to the legislators who are not stop signs: it is the purpose of a certain group of animals introduced into the action of the stop sign as sign from outside the triadicity in which alone the sign consists. And the sign itself is indifferent to the purpose to which it happens to be put! The same cry of a wolf which signifies to another wolf the prospect of sexual interaction signifies to the nearby sheep a danger to be avoided! The sign may be and normally is entangled with final causality, but not because it has a final causality. No. What it has is an objective formal specificative causality over and above its subjective being as vehicle of that specification.

\subsubsection{Modeling "maybe"}

But that specification which the sign vehicle conveys to its interpretant, lying beyond the subjectivity of the environment here and now, provides, in effect, a modeling of the possible future; and it is that virtual objectivity that engages irresistably the finalities and chance diversions at work in and among the subjectivities of nature, even inconsciently and preconsciently, but most strongly once awareness becomes part of the environmental scene.

\section{5. "Rendering inefficient relations efficient"}

How do signs act? According to Peirce, ${ }^{74}$ their essential function as relative beings is "to render inefficient relations efficient."

Let us start where the action of signs is indeed most clear to us, in the structuring of the consciousness and experience of each of us as individual animals. How does the action of signs work in this sphere of reflective consciousness distinctive of animals - human animals - able to distinguish relations from related things, and hence to know that there are signs (i.e., in their proper being as signs triadic relations, as Poinsot and Peirce separately and together have

74 Peirce 1904: CP 8.332. 
shown) in their difference from related things functioning as sign vehicles in the objective world of animals?

Here is the trajectory of these remarks: from the action of signs as working to transform an initially lifeless physical universe in the direction of being able to sustain living things, to continuing at work among those living things first brought about to increase and multiply them not only as individuals but also as species of increasing complexity and, with the emergence of animals, consciousness, but a consciousness which required the development of a biologically underdetermined Innenwelt in order to be able to model 'things' not reducible to sensory aspects of objects and hence in terms of pure relationships which, exapted, will become linguistic communication as a species-specifically unique channel of communication opening the door to the "world" of culture as over and above even though remaining as well inclusive of that partially objectified world of physical things that we call "nature".

\subsection{Semiosis as an influence of the future}

If "thought is what it is only by virtue of addressing a future thought which is more developed", as Peirce held ${ }^{75}$ and thought as consisting in signs is necessarily involved in semiosis, then, if semiosis is even contingently and, as it were, intermittently involved in the material interactions of physical things, then the physical environment is what it is (insofar as semiosis is involved) only by virtue of addressing a future state of affairs which is more developed, and one eventually, even though not initially, dependent on the thought of a community wherever a community of inquirers as semiotic animals has been able to constitute itself.

Now in human thought, how does the action of signs typically manifest itself? One principal way is by guiding our behavior in everyday affairs. I go to meet a friend, or go to a meeting to be chaired by a particular individual. Unknown to me, that friend, or that chair, is killed three hours before the scheduled meeting. I go there nonetheless, expecting to meet them in person. They are present to me as objects signified which are also things - or so I think even when the

75 Peirce 1868: CP 5.316. 
"also" no longer obtains. My thought as sign vehicle presents them to me as objects signified, equally when they are and when they are no longer things in the physical environment able to be encountered "in person". Thus signs work as an influence of the future upon the present, and the meaning of the past is shaped by that influence of the future.

The future as signified or "expected" may or may not turn out to be the future as it will come actually to be experienced. But the future as experienced is nonetheless partially shaped by the anticipated future, even when the anticipations go awry. And there is no anticipation outside semiosis. Here we have been speaking of conscious semiosis; but it should be clear that anticipation is of the essence of the action of signs not only when conscious awareness is involved, but that the very possibility of conscious anticipation springs rather from the nature of sign-action which both precedes and surrounds consciousness, even when it also involves consciousness.

How, then, can all this work in the realm of inorganic nature? Not constantly, as in the realm of life. But why not intermittently, like a match struck to light a cigarette which sputters out before it flames sufficiently to achieve its purpose? As Peirce puts it, ${ }^{76}$ "it may be that there are agencies that ought to be classed along with signs and yet that at first begin to act quite unconsciously." Thus two events in the order of brute secondness (causal interaction among physical things) bring about a new situation which, not at the moment, but at a future time when yet some third new situation comes about, give rise, for example, to a first living thing, or at least to a change of circumstance that makes the remote possibility of life more proximate than previously? At that moment when emerges the first living substance, of course, and only then, the flame of sign activity is true and properly lit. Intermittent sparks become now a conflagration.

But what about those moments leading up to that moment, those moments wherein the material interactions of things at the level of secondness yet bring about a thirdness of possibility (a "firstness of thirdness", as we might say) not at all possible prior to the specified interaction? ${ }^{77}$ Such transitions, such "leaps", must have occurred,

76 Peirce c.1907: EP2.410.

77 Here I am extending to the physiosemiosic order an observation that Peirce makes of the anthroposemiosic order (c.1906: CP 5.489): "It is not to be supposed that upon every presentation of a sign capable of producing a logical interpretant, 
since otherwise an initially lifeless universe incapable of sustaining life would have remained lifeless and remained incapable of sustaining life.

Yet we know that there was de facto a development of the physical universe which made life proximately possible prior to the advent of life, and apart from which development life would have remained impossible. Life lay far in the future at the instant of the "big bang", yet all events thereafter occurred "as if" under the influence of that far future, in the sense of occurring (not in every individual occurrence, but in the aggregate) as preparatory thereto. In broadest strokes, we can say that life requires planetary systems, and planetary systems require stars; yet neither stars nor planets were present in the universe from the beginning. The future as proximately possible in this or that way depends upon the present state of things here and now; yet those things here and now by their interactions bring about further present conditions which change the possibilities of the future and, at the same time, the relevancies of the past; because it is always those "future possibilities" which determine in any given present state of affairs the relevance of the past thereto.

Thus semiosis, as the virtual influence of the future upon the present changing the relevance of the past, may well be the essence of the action of signs, as Peirce suggested as early as $1868,{ }^{78}$ even as the

such interpretant is actually produced. The occasion may be either too early or too late. If it is too early, the semiosis will not be carried so far [...]. On the other hand," the occasion may come too late. (Here, then, is the proper place of chance in the process: central, yet not the very heart of the matter — cf. Deely 1969: 105111.) In the extension, yet still following Peirce (now 1904: CP 8.332), "we may take a sign in so broad a sense that the interpretant of it is not a thought, but an action or experience, or we may even so enlarge the meaning of sign that its interpretant is a mere quality of feeling", with the yet further qualification (c.1907: EP2.410) that "it may possibly be that I am taking too narrow a conception of the sign in general in saying that its initial effect must be of the nature of feeling, since" - as we mentioned above — "it may be that there are agencies that ought to be classed along with signs and yet that at first begin to act unconsciously", as indeed must be the case wherever it is a question of physisemiosis, as in nature prior to the advent of life. See Deely 2008a.

Peirce 1868: CP 5.316: "Finally, as what anything really is, is what it may finally come to be known to be in the ideal state of complete information, so that reality depends on the ultimate decision of the community; so thought is what it is, only by virtue of its addressing a future thought which is in its value as thought identical with it, though more developed. In this way, the existence of thought 
being of signs consists in triadic relations; and these relations enable a spiral of development whereby the future not only depends upon the present but beckons the present to draw upon the resources it has from the past in different ways than heretofore, until we reach a stage where the future exists as a state of consciousness in the awareness of animals able to envision that future according to alternatives neither given as such in nor reducible to sensation and sense perception: at that moment the human animal begins a line of development which slow by slow - falls more and more under its own control of alternative possibilities, precisely as its understanding of the subjective constitution of its physical surroundings expands through especially the idioscopic developments of science in the modern sense, according to the saying of Aquinas that "the speculative intellect becomes practical by extension".

\subsection{The transition within semiosis to semioethics}

It is this species-specifically human and semiotic capacity to envision alternatives not reducible to the animal Umwelt of objects perceived simply as desirable $(+)$, undesirable $(-)$, or safe to ignore $(0)$, which introduces into the lifeworld or Lebenswelt (the Umwelt as transformed by language and linguistic communication) the possibility of science, initially conoscopic, eventually idioscopic as well. That science is no different from the perceptual knowledge of all animals in

now depends on what is to be hereafter; so that it has only a potential existence, dependent on the future thought of the community." And as we know all thought to be in signs - thought being not only itself a semiosis but a particular semiosis, depending in its achievements on yet other semioses which are not thoughts (i.e., semioses whose interpretant "is not a thought, but an action" bringing about a thirdness even if only virtually, and semioses the "agencies [of which] ought to be classed along with signs and yet that at first begin to act quite unconsciously" so it is necessary that thought reveal something of the essence of semiosis as such, something common to every semiosis, and I am suggesting that that quintessence of sign action is an influence of the future affecting the present and reshaping the relevancy of the past. There is not always the achievement of genuine Thirdness in semiosis - for example, when it is virtual but not yet actual - but there does seem always to be an influence of the future, which seems to be the meaning of Poinsot's formula (a formula which even Short 2007: 53-56 recognizes to be operative in Peirce's doctrine of signs). See further Poinsot 1632: 126/1-32; Peirce c.1902/1903: CP 2.275; Deely 1994: Ch. 7; 2008b. 
being dependent upon the action and use of signs, but it differs from the perceptual knowledge of all other animals in being able to consider and reveal the "way things are" in their own subjectivity, their own constitution insofar as they are things existing whether or not cognized. Steel is stronger than cardboard not because either is known, but because of what each of them differently is in their subjective constitution as things of the environment; and that "is" requires recognition of the difference between objects as,,+- 0 , and objects as sometimes and in various measures things existing "things in themselves" in exactly that sense Kant falsely proclaimed to be "unknowable" - over and beyond our animal attitude towards them as,,+- 0 .

It is the fact that no awareness can be achieved without the involvement of signs that remains inaccessible to animals unable to deal with relations in their difference as suprasubjective from things as intersubjectively related. For relations cannot be perceived, only related objects; but relations in their difference from objects related can be understood, and it is this possibility of awareness that distinguishes human understanding, for it is this awareness that is essential to modeling the world in ways that do not necessarily reduce to related objects in the order of material things accessible as such to sense; but it is this awareness which also introduces, as a consequence of its unique awareness, the ultimate inescapability of responsibility.

Thus, while all animals in making use of signs depend upon semiosis throughout their life, since signs in their proper being are not sense-perceptible vehicles but triadic relations knowable as such intellectually but not perceptually, only human animals are able to know that there are signs and not simply use signs. And since the study of signs presupposes the ability to know signs as such, i.e., in their difference from the vehicles of semiosic interactions, and that being proper to signs is revealed precisely through the action of signs (semiosis), the animal able to know signs in their proper being is most properly characterized in its distinctness as the semiotic animal, the animal which rises above bare semiosis by becoming conscious of that process upon which all knowledge and life depends, as well perhaps as the process of development which leads up to and initially makes life proximately possible in a universe initially both lifeless and hostile to life. Responsibility for the continuance of the possibility in 
its actuality as an ascending development looms from the start as the horizon proper to the initial distinctiveness of anthroposemiosis.

\section{A final frontier in terrestrial semiosis: The semioethic animal}

Metasemiosis, the consciousness that there are signs with the accompanying realization of our dependence upon signs in all that we know or can come to know (whence the oxymoronic character of "metasemiotics" proposed as a term of discourse), reveals thus that the consequences of actions must be taken into account in deciding what actions to perform. That is the beginnings of ethics. But ethics has traditionally been envisaged in terms of taking responsibility for individual actions, and its semiosic character and roots have remained concealed in the standard treatments heretofore. As science and technology have become central to the lifeworld of human culture, we have begun to see that ethics in the traditional sense is not sufficient for the good of the species of semiotic animals - or any other animals, for that matter, inasmuch as semiotic animals are no different from other animals in depending upon the surrounding conditions of their physical environment to thrive or even survive.

And thus the individual ethical consciousness of human animals to behave in ways conducive to the good of the individual precisely as a member of a community expands to realize that the human community is a biological reality as well as a cultural one, and depends like every biological community upon certain conditions being preserved or developed not just in the human world of culture but in the physical environment within which that world of culture exists and upon which the human world, like the Umwelt of every animal whatever, depends for sustenance. Thus the semiotic animal become semioethical, and ethics becomes semioethics as an acceptance of responsibility not only for individual behavior but also for collective behavior, and responsibility for the consequences of behavior not only within the culture but also within the biosphere apart from which, like language divorced from zoösemiosis, the cultural world simply implodes.

Global semiotics, in the human person, implies ethics; but ethics in the human person as semiotic animal becomes semioethics. 


\section{References}

Aquinas, Thomas i.1252-1273. = Busa, Roberto (ed.) 1980. S. Thomae Aquinatis Opera Omnia ut sunt in indice thomistico. 7 vols. Stuttgart: FrommannHolzboog.

- i.1259/65. Summa Contra Gentiles. In: Busa (ed.) 1980: vol. 2, 1-152.

- c.1266/73. Summa theologiae. In: Busa (ed.) 1980: vol. 2, 184-926.

Barrow, John D.; Tipler, Frank J.; Wheeler, John A. 1988. The Anthropic Cosmological Principle. Oxford: Oxford University Press.

Bentham, Jeremy 1962 [1816]. Chrestomathia: Being a Collection of Papers, Explanatory of the Design of an Institution Proposed to be Set on Foot Under the Name of the Chrestomathic Day School, or Chrestomathic School, for the Extension of the New System of Instruction to the Higher Branches of Learning, For the Use of the Middling and Higher Ranks in Life. In: Bowring, John (ed.), The Works of Jeremy Bentham, vol. 8. New York: Russell \& Russell, 1-191.

Bense, Max 1984. The so-called 'anthropic principle' as a semiotic principle in empirical theory formation. The American Journal of Semiotics 2(4): 93-97.

Cobley, Paul 2004. 'To be' means 'to communicate'. Subject Matters 1(1): 29-46.

Dawkins, Richard 1976. The Selfish Gene. Oxford, England: Oxford University Press. [2nd ed. 1989.]

Deely, John 1969. The philosophical dimensions of the origin of species. The Thomist 33(January and April), Part I, 75-149, Part II, 251-342.

- 1980. The nonverbal inlay in linguistic communication. In: Rauch, Irmengard; Carr, Gerald F. (eds.), The Signifying Animal. Bloomington: Indiana University Press, 201-217.

- 1985. Editorial AfterWord. In: Tractatus de Signis: The Semiotic of John Poinsot. Berkeley: University of California Press, 391-514. [Electronic version hypertext-linked, Charlottesville: Intelex, 1992.]

- 1986. On the notion of phytosemiotics. In: Deely, Williams, Kruse 1986: 96103.

- 1990. Basics of Semiotics. Bloomington: Indiana University Press. [Revised and expanded in Deely 2005.]

- 1992. Semiotics and biosemiotics: Are sign-science and life-science coextensive? In: Sebeok, Thomas A.; Umiker-Sebeok, Jean (eds.), Biosemiotics: The Semiotic Web 1991. Berlin: Mouton de Gruyter, 45-75. [Revised version in Deely 1994: 151-182.]

- 1994. New Beginnings: Early Modern Philosophy and Postmodern Thought. Toronto: University of Toronto Press. [Ch. 7 (pp. 183-200) reprinted in: Colapietro, Vincent M.; Olshewsky, Thomas M. (eds.) 1996. Peirce's Doctrine of Signs. Berlin: Mouton de Gruyter, 45-67.]

- 2001a. Four Ages of Understanding: The First Postmodern Survey of Philosophy from Ancient times to the Turn of the Twenty-first Century. Toronto: University of Toronto Press. 
— 2001b. A sign is what? Sign Systems Studies 29(2): 705-743. [Reprinted in The American Journal of Semiotics 20(1/4): 1-66 (2004).]

- 2002. What Distinguishes Human Understanding? South Bend: St. Augustine's Press.

- 2003. Ne suffit jamais un corps pour faire un signe. In: Prewitt, Terry J.; Deely, John (eds.), Semiotics 2002. Ottawa: Legas, 243-248.

- 2004a. The Thomistic import of the neo-Kantian concept of Umwelt in Jakob von Uexküll. Angelicum 81(4): 711-732.

- 2004b. The semiosis of angels. The Thomist 68(2): 205-258.

- 2004c. Three essays on What is required for something to signify? In: Bankov, Kristian (ed.), Culture and Text, vol. X EFSS'2004. Sofia: New Bulgarian University Press, 13-80.

- 2005. Basics of Semiotics. Expanded 4th Edition. (Tartu Semiotics Library 4.) Tartu: Tartu University Press.

- 2006a. The literal, the metaphorical, and the price of semiotics: An essay on philosophy of language and the doctrine of signs. Semiotica 161(1/4): 9-74.

- 2006b. Let us not lose sight of the forest for the trees ... ; A commentary on Frederik Stjernfelt's review of the Four Ages of Understanding history of semiotics within the history of philosophy. Cybernetics \& Human Knowing 13(3/4): 161-193.

- 2007a. The primary modeling system in animals. In: Petrilli, Susan (ed.), Philosophy of Language as the Art of Listening: On Augusto Ponzio's Scientific Research. Bari: Edizione dal Sud, 161-179.

- 2007b. Intentionality and Semiotics. Scranton: Scranton University Press.

- 2008a. Evolution, semiosis, and ethics: rethinking the context of natural law. In: González, Ana Marta (ed.), Contemporary Perspectives on Natural Law. Aldershot: Ashgate, 413-442.

- 2008b. To find our way in these dark woods versus coming up Short. Recherche Semiotique/Semiotic Inquiry 26(2/3): 165-234 [2006].

- 2008c. Descartes \& Poinsot: The Crossroad of Signs and Ideas. Scranton: Scranton University Press.

Deely, John N.; Williams, Brooke; Kruse, Felicia E. (eds.) 1986. Frontiers in Semiotics. Bloomington: Indiana University Press. [Preface titled "Pars Pro Toto", pp. viii-xvii; "Description of Contributions", pp. xviii-xxii.]

Dennett, Daniel 1995. Darwin's Dangerous Idea: Evolution and the Meanings of Life. New York: Simon \& Schuster.

Doyle, John P. 1985. The Conimbricenses on the relations involved in signs. In: Deely, John (ed.), Semiotics 1984. Lanham: University Press of America, 567-576.

Doyle, John P. (ed. and trans.) 2001. The Conimbricenses: Some Questions on Signs (Medieval Philosophical Texts in Translation). Milwaukee: Marquette University Press. [Bilingual critical edition of Conimbricenses 1607, q. v.]

Emmeche, Claus 1994. The Garden in the Machine. Princeton: Princeton University Press.

Krampen, Martin 1986. Phytosemiotics. In: Deely, Williams, Kruse 1986: 83-95. 
Levinas, Emmanuel 1974. Autrement qu'être ou au-dela de l'essence. The Hague: Nijhoff.

Lieb, Irwin C. 1953. Charles S. Peirce's Letters to Lady Welby. New Haven: Whitlock's, Inc.

Maritain, Jacques 1959 [1932]. Distinguish to Unite, or The Degrees of Knowledge (trans. from the 4th French ed. under the supervision of Gerald B. Phelan). New York: Charles Scribner's Sons.

- 1966 [1963]. God and the Permission of Evil. (Owens, Joseph, trans.) Milwaukee: Bruce.

Nöth, Winfried; Kull, Kalevi (eds.) 2001. Semiotics of nature. Special Issue of Sign Systems Studies 29(1).

Peirce, Charles Sanders 1868. Some consequence of four incapacities. Journal of Speculative Philosophy 2: 140-157. [Reprinted in CP 5.264-317.]

- 1901. CP 1.133-134 are editorially entitled "§3. The Observational Part of Philosophy". [This title has a footnote which reads "From 'The Idea of a Law of Nature among the contemporaries of David Hume and among advanced thinkers of the present day', c.1894". However, in CP 8, in the Burks Bibliography for 1901: 2(a), p. 290, dates this same text to 1901. I have not been able to examine the ground of the conflict, but follow Burks as the later authority to investigate the question.]

- c.1902. Minute Logic. [Draft for a book complete consecutively only to Chapter 4. Published in CP in extracts scattered over six of the eight volumes, including $1.203-283,1.575-584 ; 2.1-202 ; 4.227-323,6.349-352 ; 7.279$, 7.374n10, 7.362-387 except 381n19. (For fuller detail, see Burks 293-294.)]

- c.1902/1903. Syllabus. [CP 2.274-277, 2.283-284, 2.292-294, 2.309-331 (with 2.309 continuing 2.294) are from it. The Peirce Edition Project currently deems 1903 the most likely date of composition.]

- 1903. Lowell lectures: Some topics of logic bearing on questions now vexed. [Esp.: lect. IIIA, "Lessons from the History of Philosophy", CP 1.15-26; draft 3 of lect. 3 entitled "Degenerate Cases", in CP 1.521-544; lect. 8, "How To Theorize", CP 5.590-604 (Burks p. 295); and the section published in CP 4.510-529 under the title "The Gamma Part of Existential Graphs".]

- 1904. Photostat copy of a letters in the Yale University Library, On signs and the categories, dated 12 Oct 1904, partially reproduced in CP 8.327-341; published in full in Lieb 1953.

- 1905. Review of Wilhelm Wundt's Principles of Physiological Psychology, Vol. 1.81 (20 July 1905) 56-57. Reprinted in CP 8.196-204, except $201 \mathrm{n} 3$ ([Bibliography] G-c.1905-9) which is from a draft in Widener.

- 1905a. Issues of pragmaticism. CP 5.438-463 (except 448n1); reprinted from The Monist 15(October), 481-499.

- 1906. MS 283. [Partially published in CP 1.573-574, 5.448n, and 5.449-454; more completely in EP 2.371-397 and 544n22.]

- 1906a. MS 793. [Partially published in EP 544n22 and by Joseph Ransdell in the "Peirce Discussion Forum <peirce-1@1yris.ttu.edu>" for 04 November 2006 (02:48 hours).] 
- 1906b. Basis of pragmaticism. [Portion published as CP 5.488n1, in six paragraphs.]

- c.1906. "Pragmatism (Editor [3])", in CP 5.11-13, except 5.13n1, and 5.464496, with 5.464 continuing 5.13, (both dated c.1906) are from it. CP 5.11-13 were previously printed in The Hound and Horn 2 (April-June 1929): 282285, under the title "The Founding of Pragmatism".

- c.1906a. "Phaneroscopy $\varphi \alpha \nu$ " of 1905 has also portions dated c.1906 published in CP 1.306-311, 4.6-11, 4.53n1, 4.553n1 (p. 441): following Burks 1958: 298 re 1905(h).

- c.1907. Ms. 318. In: Robin, Richard, Annotated Catalogue of the Papers of Charles S. Peirce. Amherst: University of Massachusetts Press, 1967, 36-37 (numbered ISP 00002-00350). [The most complete, but still partial, presentation of this document is in EP 2.398-433, under the title "Pragmatism".]

Petrilli, Susan 2003. Modeling, dialogue, and globality: Biosemiotics and semiotics of self. 2. Biosemiotics, semiotics of self, and semioethics. Sign Systems Studies 31(1): 65-107.

- 2008. On communication: Contributions to the human sciences and to humanism from semiotics understood as semioethics. The American Journal of Semiotics 24(4): 193-236.

Petrilli, Susan; Ponzio, Augusto 2003. Semioetica. Roma: Meltemi.

Poinsot, John 1985 [1632]. Tractatus de Signis: The Semiotic of John Poinsot. Deely, John; Powell, Ralph Austin (eds.). Berkeley: University of California Press. [Available in electronic form Charlottesville, Virginia: Intelex Corporation, 1992].

Ratzinger, Joseph 1970. Introduction to Christianity. New York: Herder and Herder.

Saussure, Ferdinand de 1916. Cours de Linguistique Generale. (Bally, Charles; Sechehaye, Albert, eds.) Lausanne: Payot.

Sebeok, Thomas A. 1963. Communication in animals and men. Language 39: 448-466.

- 1978. 'Talking' with animals: Zoosemiotics explained. Animals 111(6): 2023, 36. [Reprinted in Deely, Williams, Kruse 1986: 76-82.]

- 1985a. Vital signs. The American Journal of Semiotics 3(3): 1-27. [Reprinted in Sebeok 1986: 59-79.]

- 1985b [1976]. Contributions to the Doctrine of Signs. (Sources in Semiotics 4.) Lanham: University Press of America.

- 1986. Communication, language, and speech: Evolutionary considerations. In: Sebeok, Thomas, I Think I Am a Verb. New York: Plenum Press: 10-16. ei viita

Short, Thomas L. 2007. Peirce's Theory of Signs. Cambridge: Cambridge University Press.

Simpson, George Gaylord 1964. This View of Life: the World of an Evolutionist. New York: Harcourt, Brace, and World.

Stjernfelt, Frederik 2006. Let us not get too far ahead of the story ... : A history of realist semiotics? Cybernetics \& Human Knowing 13(1): 91-103. [Review of Deely 2001a, with a response by Deely 2006b.] 
Todorov, Tzvetan 1978. The birth of Occidental semiotics. In: Bailey, Richard W.; Matejka, L.; Steiner, P. (eds.), The Sign: Semiotics Around the World. Ann Arbor: Michigan Slavic Publications, 1-42.

Waddington, Conrad Hal 1960. Evolutionary adaptation. In: Tax, Sol (ed.), Evolution After Darwin: Vol. 1, The Evolution of Life. Chicago: University of Chicago Press, 381-402.

- 1961. Ch. 9. The biological evolutionary system. In: Waddington, Conrad Hal, The Ethical Animal. New York: Atheneum, 84-100.

Wheeler, John Archibald 1977. Genesis and observership. In: Butts, Robert E.; Hintikka, Jaakko (eds.), Foundational problems in the special sciences. Dordrecht: Reidel, 3-33.

Whitaker, M. A. B. 1988. On Hacking's criticism of the Wheeler anthropic principle. Mind 97(386): 259-264.

\section{От семиозиса к семиоэтике: широкая перспектива действия знаков}

То, как что-либо действует, зависит от того, чем это «что-либо» является, причем, как от типа предмета, так и от определенной личности этого типа: agere sequitur esse, т.е. действие опосредовано бытием. Это справедливо как в случае знаков, так и в случае львов или сороконожек: следовательно, для того, чтобы определить диапазон или распространение семиозиса, нам необходимо прежде всего определить, к какому типу относится то, что называется «знаком». Еще Пуансо утверждал (а столетия спустя это подтвердили работы Пирса), что истинное существование знаков в качестве знаков заключается в отношении, в нередуцируемых взаимоотношениях, объединяющих три различных члена: член переднего плана, репрезентирующий иное, чем является он сам, - репрезентамен, или носитель знака; другой член, репрезентируемый, - сигнификат, или обозначаемый объект, и третий член, для которого (или которому) делается вся эта «репрезентация другого», - интерпретанта, которая не обязательно должна быть человеком и даже просто одушевленным существом. Тем самым, действие знака - это способ его воздействия на мир, не только включая мир опыта и знания, но и распространяя это воздействие даже на материальный мир природы, причем, не только живой природы. Вопрос в том, какова причинная связь, причинность (каузальность), присущая знакам вследствие свойственного для них бытия в качестве знаков; как непрямая, косвенная причинность, так и отношения косвенно зависят от взаимоодействий индивидов, создающих множественность мира. 
Вопрос и в том, какова причинность (каузальность), которая моделирует то, что должно или может быть, - по контрасту с тем, что имеется здесь и теперь. Связывать эту причинность с целевой корректно лишь в том случае, если знаки используются для формирования взаимодействия отдельных вещей, но приравнивать эту причинность с «телеологией» - основное заблуждение, которое характерно для современного развития семиотики; во многом это заблуждение обусловлено некоторыми публикациями отдельных пассажей из работы Пирса, в которой он исправляет эту ошибку, но лишь в других пассажах из нее, которые столь долго оставались неопубликованными. Вынося на свет эти пассажи, в которых Пирс движется точно в том направлении, которое ранее было указано Пуансо, данная статья предпринимает попытку своего рода обзора современного развития семиотики, обзора, в котором намечается полный объем семиозиса и показывается его коэкстенсивность с границами самого универсума, где бы они ни были. Именно косвенная, внешне детализированная формальная причинность (каузальность), которую проявляют знаки, делает возможным «влияние будущего», согласно которому семиозис меняет релевантность прошлого по отношению к будущему путем взаимодействия со Вторичностью. Понимание этого положения (причинность, присущая знакам) также делает очевидной ошибку сведения всего универсума к знакам, ошибку, иногда именуемую «пансемиозисом».

\section{Semiootikast semioeetikani: märgitoime koguulatus}

Kuidas miski toimib, sõltub sellest, mis see miski on, nii sellest, mis liiki asi ta on, kui ka temast kui konkreetsest indiviidist selle liigi sees: ager segitur esse ehk toime johtub olemusest. See kehtib ühtmoodi nii märkide, lõvide kui sajajalgsete kohta. See tähendab, et semioosi ulatuse määramiseks on meil ennekõike vaja määrata, mis liiki see "märgiks" nimetatud asi õieti on. Juba Poinsot väitis (ja sajandeid hiljem kinnitasid tema öeldut Peirce'i tööd), et märkide kui märkide tõeline olemus seisneb suhtes. Suhtes, mis ühendab kolme eraldi liiget ja on vähematele koostisosadele taandamatu: esiplaanil asuv liige, mis esitab midagi muud, kui ta ise on - esitis ehk märgikandja; seejärel see teine, mida esitatakse - tähistatu ehk tähistatav objekt; ja kolmas liige, kellele või kelle tarvis seda teist esitatakse - tõlgend, mis ei pea ilmtingimata olema isik ja ei pea õigupoolest isegi hingestatud olend olema. Märgitoime on seega 
viis, kuidas märgid mõjutavad maailma, sealhulgas kogemuse ja teadmise ilmast eluvälise looduse füüsilise maailmani välja. Oluline on see, milline on märkidele vastav põhjuslikkus, mis tuleneb nende kui märkide tõelisest olemusest. See on kaudne põhjuslikkus, kuivõrd suhted sõltuvad kaudselt indiviidide omavahelistest vastastikustest toimetest, millest koosneb maailma mitmekesisus, ja ühtlasi on see põhjuslikkus, mis kujundab selle, mis võiks olla, vastandina sellele, mis siin ja praegu on. Seostada seda põhjuslikkust eesmärgipärase põhjuslikkusega on korrektne, seni kuni märke kasutatakse üksikute asjade vastastoime kujundamisel. Kuid võrdsustada seda põhjuslikkust "teleoloogiaga" oleks põhimõtteline viga, mille poole kaasaegne semiootika on kippunud kalduma. See viga on sündinud suuresti tänu avaldatud osale ühest teatud Peirce'i esseest. Edasi Peirce parandab selle vea, osutades juba varem Poinsot' poolt maha märgitud suunas, kuid need lõigud esseest on jäänud avaldamata. Käesolev artikkel toob need avaldamata lõigud uuesti avalikkuse ette ja üritab anda ülevaadet kaasaegse semiootika arengust, manades esile semioosi kogu selles ulatuses ja demonstreerides, et semioosi piirid kattuvad universumi piiridega, kus iganes need ka ei oleks. Just märkide kaudne, väliselt määratlev vormiline põhjuslikkus teeb võimalikuks "tuleviku mõju", mis tähendab, et semioos muudab teisesuse vastutoimete kaudu mineviku olulisust oleviku jaoks. Märkidele omase põhjuslikkuse mõistmine paljastab ka universumi märkidele taandamise ehk pansemioosi ekslikkuse. 